\title{
Türkiye'de Uzamsal Yeteneğe ilişkin Araştırma Eğilimleri
}

\author{
DOI: $10.26466 /$ opus.839496
}

\section{Neșe Dokumacı Sütçü *}

* Dr, Dicle Üniversitesi, Eğitim Fakültesi, Diyarbakır/Türkiye

\author{
E-Posta: ndokumaci@dicle.edu.tr \\ ORCID: 0000-0003-3279-4194
}

\section{Öz}

Bu araştırmada, Türkiye'de 1996 ile 2020 yılları arasında yapılmış olan uzamsal yeteneğe ilişkin araştırma eğilimlerinin belirlenmesi amaçlanmıştır. Bu amaçla 88 lisansüstü tez incelenmiştir. Araştırmada, nitel araştırma türlerinden olan doküman inceleme kullanılmıştır. Araştırma kapsamına giren tezler ölçüt örnekleme ile belirlenmiştir. Elde edilen verilerin çözümlenmesinde içerik analizi kullanılmıştır. Araştırmada uzamsal yetenek ile ilgili yapılmış olan yüksek lisans tezlerinin sayısının doktora tezlerine göre daha fazla olduğu; yüksek lisans tezlerinin en çok 2016 ve 2018, doktora tezlerinin ise 2012, 2017 ve 2019 yıllarında yapıldığ ; a ăırlıklı olarak doktora tezlerinin profesörlerin, yüksek lisans tezlerinin ise doktor öğretim üyesi danışmanlı̆̆ında olduğu; en çok lisansüstü tez yapılan üniversitelerin Ortadoğu Teknik ve Marmara olduğu, enstitülerin Ĕ̆itim ve Fen Bilimleri, anabilim dalının Ilkö̆ğretim olduğu; tezlerde en çok "farkl uygulamaların uzamsal yeteneğin gelişimi üzerindeki etkileri" amacına odaklanıldığı; araştırma yöntemlerinden en fazla nicel ve karma araştırmanın, araştırma desenlerinden en çok deneysel deseninin tercih edildiği; en çok ortaokul öğrencileri ile çalışıldı ̆̆g; basit tesadüfî örnekleme yönteminin kullanıldığı; 1-50 kişilik örneklem büyüklüğ̈̈nün tercih edildiği; tezlerin çoğunda tercih edilen veri toplama aracının test olduğu; betimsel istatistiklerin en fazla tercih edilen

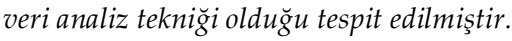

Anahtar Kelimeler: $\quad$ Uzamsal Yetenek, Araştırma Ĕ̆ilimleri, Doküman Analizi, İçerik Analizi. 
ISSN: 2528-9527

E-ISSN : 2528-9535

Yıl Year: 11

Cilt Volume: 17

Sayı Issue:36

\title{
Research Tendencies Towards Spatial Ability in Turkey
}

\begin{abstract}
In this research, it was aimed to determine the research tendencies towards spatial ability between 19962020 in Turkey. Accordingly, 88 theses were examined. The study was designed with document review which is one of the qualitative research methods. The theses were determined with criterion sampling. Content analysis was used in the analysis. It was determined that the number of master's theses conducted on spatial ability were more than the doctoral theses, the highest number of master's theses were written in 2016 and 2018 and the highest number of doctoral theses were written in 2012, 2017 and 2019, the advisors of doctoral theses were mostly professors and the advisors of master's theses were mostly assistant professor, the highest number of these were conducted in Middle East Technical and Marmara University, and the institutions were Education and Science institutions, and the departments were Elementary, the most intended purpose were "effects on the spatial ability of the different applications", the most used research method was quantitative and mixed research, the most preferred research design was experimental design, the most studied group was middle-school students, simple random sampling method was used, sample size of 1-50 people was preferred, the most preferred data collection tool was tests, and the most preferred data analysis technique was descriptive statistics.
\end{abstract}

Keywords: spatial ability, research tendencies, document analysis, content analysis 


\section{Giriş}

Uzamsal yetenek ile ilgili araştırmalar, derin olduğu kadar uzun bir geçmişe sahiptir. Neredeyse her çalışma alanı ile uzamsal yeteneğin ne olduğunu, insan aklına nasıl katkıda bulunduğunu, diğer faktörler veya değişkenleri etkileyip etkileyemediğini belirlemek için çok sayıda araştırma yapılmıştır (Hartman ve Bertoline, 2005). Uzamsal yetenek ile ilgili çalışmalar, ilk olarak Galton (1883) tarafından yapılan sistematik psikoloji araştırmaları ile incelenmeye başlanmıştır. Daha sonraları Spearman (1927) ve Thurstone (1938) gibi araştırmacılar giderek daha karmaşık istatistiksel yöntemlerle insan zekâsının yapısını çeşitli şekillerde açıklığa kavuşturmaya çalışmışlardır (Bishop, 1980). Uzamsal yetenek üzerine yapılan çalışmaları Eliot ve Smith (1983) üç aşamaya ayırmıştır. Birinci aşamada (1904-1938) araştırmacılar, genel zekâ faktörünün üzerinde uzamsal yeteneğin herhangi bir etkisini olup olmad1ğını araştırmışlardır. İkinci aşamada (1938-1961) uzamsal yeteneğin hangi alt faktörlere ayrıldığını ve alt faktörlerin birbirinden ne derece farklılaştığını belirlemeye çalışmışlardır. Üçüncü aşamada (1961-1982) diğer yeteneklerin karmaşı ilişkileri içinde uzamsal yeteneğin yerini belirlemeye ve uzamsal yetenek testlerindeki performansı etkileyen değişkenleri incelemeye çalışmışlardır. Mohler (2006), 1980'lerden günümüze kadar olan zaman dilimi içerisinde ise önceki çalışmalardaki konuların araştırılmaya devam edildiğini ve özel olarak teknolojinin uzamsal yeteneğin ölçülmesi, incelenmesi ve geliştirilmesi üzerinde etkisinin araştırıldığını ifade etmiştir.

Uzun bir geçmişi olan uzamsal yetenek, günümüzde de halen birçok disiplinde araştırılmaya devam edilmektedir. Birçok disiplinde araştırmalara konu olan uzamsal yetenek ile ilgili çok sayıda araştırmacı tarafından farklı tanımlar yapılmıştır. Uzamsal yetenek; insanların uzamsal ilişkileri, görseluzamsal görevleri ve uzaydaki nesnelerin yönelimini etkili bir şekilde ele almasını sağlayan bilişsel işlevlerdir (Sjölinder, 1998). İyi yapılandırılmış görsel bir imgeyi oluşturabilme, devam ettirebilme, yeniden düzenleme ve başka bir şekle dönüştürebilme becerisidir (Lohman, 1993). Uzamsal bilişte yer alan bilgi ve işleyiş arasındaki etkileşimi gerçekleştiren zihinsel bir süreçtir (Hauptman, 2010). Uzamsal yeteneğin tanımlanmasındaki çeşitlilik, bu yeteneğin farklı bileşenlerde incelenmesinde hatta aynı bileşenlerin farklı isimlerle adlandırılmasında da görülmektedir. Literatürde uzamsal yeteneğin sınıflan- 
dırılmasına yönelik yapılan araştırmalar (Clements, 1998; Contero, Company, Saorin, Naya ve Conesa, 2005; Linn ve Petersen, 1985; Lohman, 1979; McGee, 1979; Pellegrino, Alderton ve Shute, 1984; Pittalis ve Christou, 2010; Tartre, 1990) bu yeteneğin uzamsal görselleştirme, uzamsal yönelim, uzamsal alg1, uzamsal ilişkiler, zihinde döndürme gibi iki, üç veya daha fazla bileşenden oluştuğunu savunmaktadırlar.

Etrafımızda gördüğümüz görsel uyaranların zihinde bir görüntüsünü oluşturma ve bu görüntüleri zihinde manipüle edebilme becerisi olan uzamsal yetenek günlük hayatta birçok görevi başarmada olduğu gibi başta matematik ve geometri olmak üzere birçok disiplinle de pozitif ilişki içerisinde olup, önemli role sahiptir. Hartman ve Bertoline (2005), uzamsal yeteneğin önemini vurgulayan çok sayıda araştırma olduğunu; sanat ve eğitimden, fen ve mühendislik alanlarına uzanan araştırmaların uzamsal yeteneğe odaklandıklarını belirtmişlerdir. Newcombe ve Shipley (2015), bu dünyada yaratıcı olmak, yeni araçlar ve habitatlar tasarlamak için üst düzey uzamsal yeteneğe sahip olmak gerektiğini ifade etmişlerdir. Turgut (2015) mühendislik ve temel bilimler de dâhil olmak üzere çeşitli disiplinler için önemli olan uzamsal yeteneğin; bir kişinin olguları görselleştirmesine, düzenlemesine, yeniden yapılandırmasına ve genelleştirmesine olanak tanıdığını ve bu yeteneğin makine mühendisliği, pilot eğitimi ve bilimsel olay yeri araştırması gibi çeşitli işyeri ortamlarında gerekli olduğunu ifade etmiştir.

Uzamsal yetenek ile ilgili yapılan araştırmalar incelendiğinde, bazı araştırmalarda ortaokul öğrencilerinin uzamsal görselleştirme (Dokumacı Sütçü, 2018; Turgut ve Yllmaz, 2012); zihinde döndürme (İrioğlu ve Ertekin, 2012) ve uzamsal ilişkiler (Turgut ve Yılmaz, 2012); öğretmen adaylarının uzamsal düşünme (Turgut, Yenilmez ve Balbağ 2017) ve uzamsal görselleştirme (Abay, Tertemiz ve Gökbulut, 2018; Erkek, Işıksal ve Çakıroğlu, 2017; Göktepe Yıldız ve Özdemir, 2017; Sarı, 2016; Turgut ve Yenilmez, 2012) düzeyleri belirlenmiş ve farklı değişkenler açısından incelenmiştir. Diğer taraftan uzamsal yetenek ile ilgili yapılan bazı araştırmalarda geometrik-mekanik zeka oyunları (Demirkaya ve Masal, 2017; Dokumacı Sütçü, 2017; Newman, Hansen ve Gutierrez, 2016; Olkun, 2003b), mühendislik çizim aktiviteleri (Olkun, 2003a), bilgisayar yazılımları (Güven ve Kösa, 2008; Şimşek ve Koru Yücekaya, 2014), dijital oyunlar (Corradini, 2011; Lin ve Chen, 2016; MartinDorta vd., 2014), manipulatifler (Yıldız ve Tüzün, 2011; Yurt ve Sünbül, 2012) 
gibi birçok materyal ve etkinliklerden yararlanılarak uzamsal becerilerin geliştirilmesi amaçlanmıştır. Uzamsal yetenek ile ilgili diğer bazı araştırmalarda ise uzamsal becerilerin matematik ve geometri (Cheng ve Mix, 2014; Kospentaris ve Spyrou, 2010; Lowrie, Logan ve Ramful, 2017), fen (Tracy, 1990), fizik (Delialioğlu ve Aşkar, 1999; Liner, 2012; Pallrand ve Seeber, 1984), kimya (Coleman ve Gotch, 1998; Pribyl ve Bodner, 1987), biyoloji (Russell-Gebbett, 1985), mühendislik (Peters, Chisholm ve Laeng, 1995) gibi alanlarla olan ilişkisi incelenmiştir. Dahası uzamsal yetenek ile ilgili bazı araştırmalarda da uzamsal beceriler ile uzamsal kaygı (Sarı, 2016), matematiksel muhakeme (Gürbüz, Erdem ve Gülburnu, 2018), mantıksal düşünme (Turgut, Yenilmez ve Balbağ, 2017), matematik kaygisı (Ferguson, Maloney, Fugelsang ve Risko, 2015) arasındaki ilişki incelenmiştir. Görüldüğü üzere uzamsal yetenek ile ilgili yapılan araştırmalar farklı amaçlar için yapılmış, araştırmalarda uzamsal yeteneğin farklı bileşenleri ele alınmış, farklı örneklemlerle çalışılmış, farklı araştırma yöntemleri, desenleri ve veri analiz yöntemleri kullanılmıştır. Bu araştırmada ise, Türkiye'de uzamsal yetenek ile ilgili yapılmış olan çalışmaların genel bir durumunu ortaya koymak amaciyla, 1996-2020 yılları arasında uzamsal yetenek ile ilgili yapılmış olan lisansüstü tezlerin incelenmesi amaçlanmıştır. Bu amaç doğrultusunda, uzamsal yetenek ile ilgili yapılmış lisanüstü tezlerin türleri, yazıldığı diller, yıllar, danışman unvanları, yürütüldügü̈ üniversiteler, enstitüler, anabilim dalları, tezlerde ulaşılmak istenen amaçlar, kullanılan araştırma yöntemleri, araştırma desenleri, çalışılan hedef kitleler, yararlanılan örnekleme yöntemleri, tercih edilen örneklem büyüklükleri, kullanılan veri toplama araçları ve veri analiz teknikleri açısından incelenmiştir. Yapılan araştırmaları kapsamlı olarak incelemek, ileride uzamsal yetenek ile ilgili çalışma yapmak isteyen araştırmacılara konu ile ilgili fikir verebilmek ve konu alanında var olan eksiklikleri tespit edebilmek açısından böyle bir araştırma yapmaya ihtiyaç duyulmuştur.

\section{Yöntem}

\section{Araştırma Deseni}

Araştırmada nitel araştırma türlerinden olan "doküman inceleme (belgesel tarama)" kullanılmıştır (Sönmez ve Alacapınar, 2016). Doküman inceleme, araştırma verilerinin birincil kaynağı olarak çeşitli dokümanların toplanması, gözden geçirilmesi, sorgulanması ve analizi olarak tanımlanabilen bilimsel 
bir araştırma yöntemidir (O'leary, 2004; Akt: Özkan, 2019). Doküman inceleme; kitaplar, dergiler, makaleler, tezler gibi yazıll; resimler, filmler, araç gereçler gibi görsel malzemelerin toplanıp, sistemli olarak incelenmesi olarak da tanımlanabilir (Sönmez ve Alacapınar, 2016). Doküman incelemede araştırma problemi doğrultusunda hangi dokümanların analiz edileceğine karar verilmektedir (Cansız Aktaş, 2015).

\section{Verilerin Toplanması}

Araştırma kapsamına giren, Türkiye'deki uzamsal yetenek ile ilgili hazırlanmış lisansüstü tezler, ölçüt örnekleme ile belirlenmiştir. Burada temel alınan ölçütler; Yükseköğretim Kurulu Tez Dokümantasyon Merkezi'nde anahtar kelimelerde ve tez başlı̆̆ında "uzamsal yetenek"; uzamsal yeteneğin literatürdeki diğer adlandırmaları olan "uzamsal beceri, uzamsal düşünme, görsel-uzamsal yetenek, uzamsal akıl yürütme"; uzamsal yeteneğin literatürdeki önemli bileşenlerinden olan "uzamsal görselleştirme, uzamsal yönelim, uzamsal ilişkiler, zihinde döndürme, zihinsel döndürme, zihinsel çevirme" kelimeleri bulunan tezlerin yer almasıdır. Bu kapsamda Yükseköğretim Kurulu Tez Dokümantasyon Merkezine kayıtll, pdf formatında tam metinlerine ulaşılan 88 adet teze ulaşılmıştır. Ulaşılan tezler Yazar ve Dokumacı Sütçü (2018) tarafından geliştirilen tez inceleme formundan yararlanılarak incelenmiştir.

\section{Verilerin Analizi}

Araştırmada nitel araştırmanın analiz yöntemlerinden biri olan içerik analizi kullanılmıştır. İçerik analizinde, birbirine benzer veriler belirli kavramlar ve temalar çerçevesinde bir araya getirilir ve düzenlenen veriler okuyucunun anlayacağ 1 bir biçimde düzenlenerek yorumlanır (Yıldırım ve Şimşek, 2011). Araştırmada elde edilen veriler, kategorilere göre araştırmacı tarafından tez inceleme formuna kodlanmıştır. Verilerin çözümlenmesinde frekanstan (f) yararlanılmış ve veriler grafikler şeklinde sunulmuştur.

Araştırmada elde edilen veriler, araştırmacı tarafından kategorilere göre titizlikle okunmuş, incelenmiş ve forma kodlanmıştır. Kodlama güvenirliğinin sağlanması için analizler bir ay sonra tekrarlanmış ve kodların uyum oranı Miles ve Huberman (1994)'ın önerdiği güvenirlik formülüyle hesaplanmış ve kodlama tutarlılığ1 \%93 olduğu belirlenmiştir. Miles ve Huberman 
(1994) 'a göre güvenirlik hesaplarının \%70'in üzerine çıkması, bu araştırmanın güvenilir olduğunu göstermektedir. Ayrıca araştırmacı tarafından yapılan kodlamalar matematik eğitimi alanında uzman iki öğretim üyesi tarafından da kontrol edilmiştir.

\section{Bulgular}

Ülkemizde 1996-2020 yılları arasında uzamsal yetenek ile ilgili yapılan lisansüstü tezlerin incelenmesi amacıyla yapılan bu araştırmada 88 lisansüstü tez incelenmiştir. Bazı tablolarda verilen frekans değerleri, incelenen lisansüstü tez sayısından fazla olmaktadır. Bu durum bazı tezlerin iki danışmanla yürütülmesinden, birden fazla amaçta tasarlanmasından; tezlerde birden fazla araştırma deseninden, örneklem grubundan, örnekleme yönteminden, veri toplama aracından, veri analiz tekniğinden yararlanılmasından ve bunların tabloda ayrı bir frekans olarak belirtilmesinden kaynaklanmaktadır.

Lisansüstü tezlerin türlerine göre dağılımlarına Grafik 1'de yer verilmiştir.

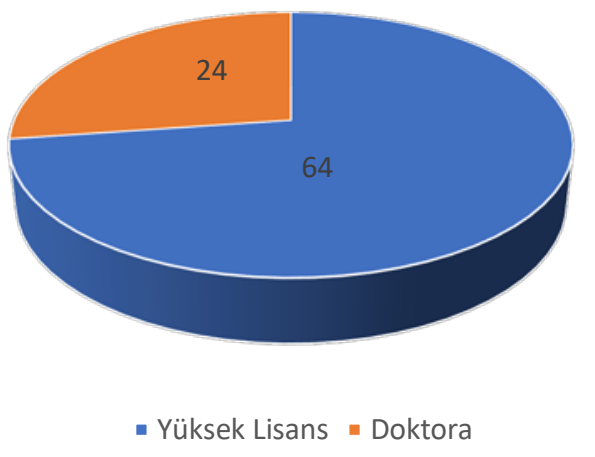

Grafik 1. Türlere Göre Dağılımlar

Grafik 1'deki uzamsal yetenek ile ilgili yapılmış olan lisansüstü tezlerin türlerine göre dağılımları incelendiğinde, tezlerin çoğunu yüksek lisans tezlerinin ( $\mathrm{f}=64)$, daha az kısmını doktora tezlerinin ( $\mathrm{f}=24$ ) oluşturduğu görülmektedir.

Uzamsal yetenek ile ilgili yapılmış olan lisansüstü tezlerin yazıldığı dillere göre dağılımları Grafik 2'de verilmiştir. 


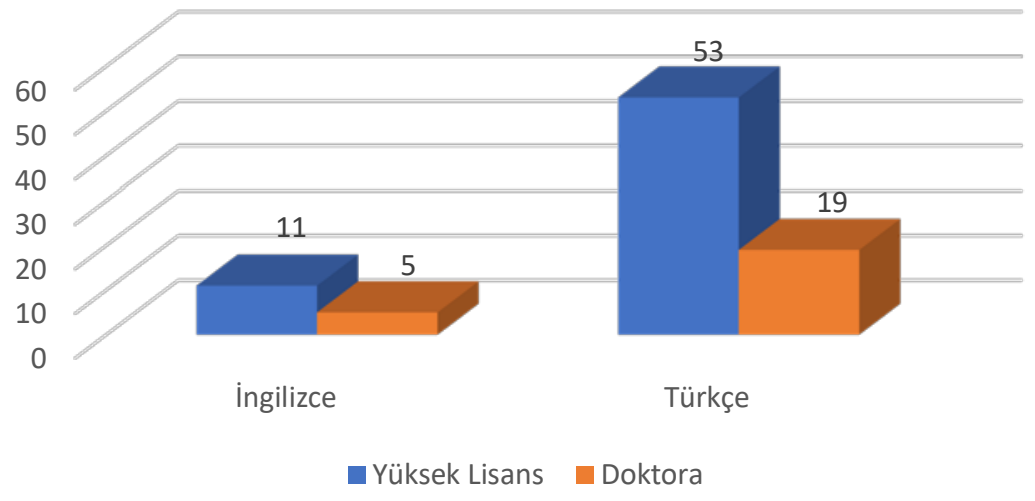

Grafik 2. Dillere Göre Dağılımlar

Grafik 2 incelendiğinde, uzamsal yetenek ile ilgili yapılmış olan lisansüstü tezlerin çoğunun Türkçe ( $\mathrm{f}=72$ ) yazıldığı, geri kalan kısmının ise İngilizce $(\mathrm{f}=16)$ yazıldı̆̆ 1 görülmektedir.

Uzamsal yetenek ile ilgili yapılmış olan lisansüstü tezlerin gerçekleştirildiği yıllara göre dağılımlarına Grafik 3'te yer verilmiştir.

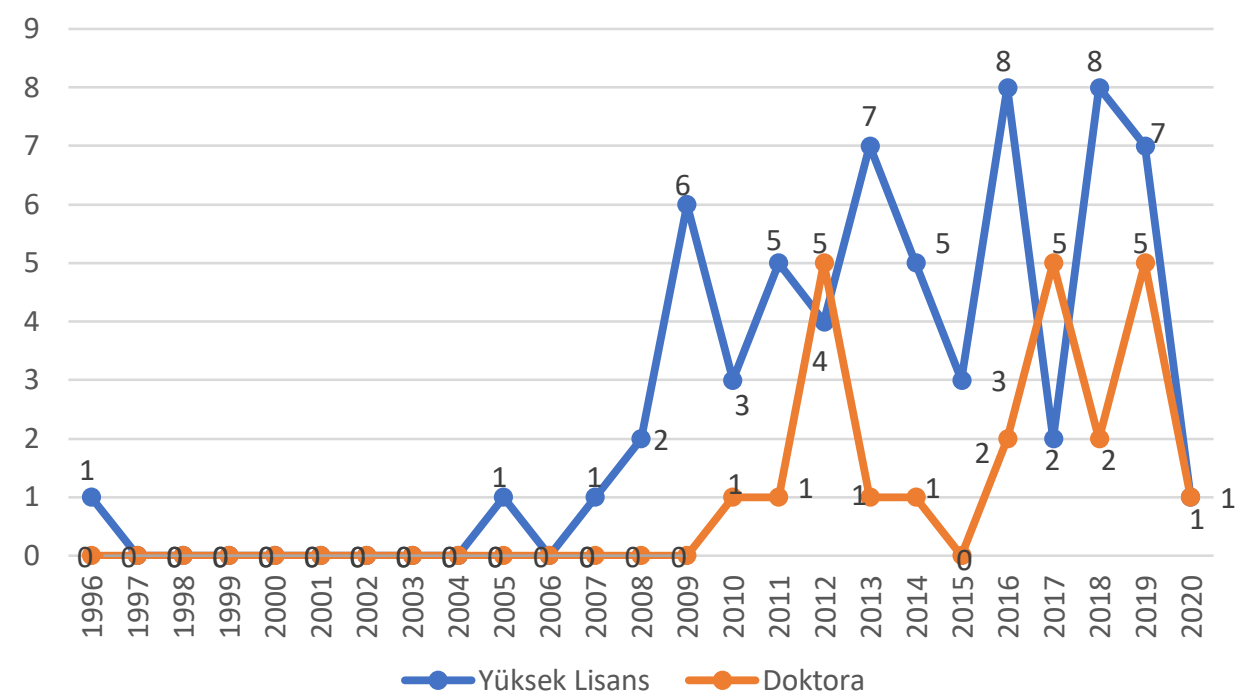

Grafik 3. Yallara Göre Dă̆ı̆lımlar 
Grafik 3'te, uzamsal yetenek ile ilgili yapılmış olan yüksek lisans tezlerinin en çok 2016 ( $\mathrm{f}=8$ ) ve $2018(\mathrm{f}=8)$; doktora tezlerinin ise 2012 ( $\mathrm{f}=5), 2017(\mathrm{f}=5)$ ve 2019 (f=5) yıllarında gerçekleştirildiği görülmektedir. 1997-2004 yılları arasında yüksek lisans tezi, 1996-2009 yılları arasında ise doktora tezi yapılmamıştır. Uzamsal yetenek ile ilgili doktora tezi ilk olarak 2010 yılında yapılmıştır. Toplamda en fazla lisansüstü tez 2019 ( $\mathrm{f}=12$ ) yılında yapılmıştır.

Uzamsal yetenek ile ilgili yapılmış olan lisansüstü tezlerin danışman unvanlarına göre dağılımları Grafik 4'te verilmiştir.

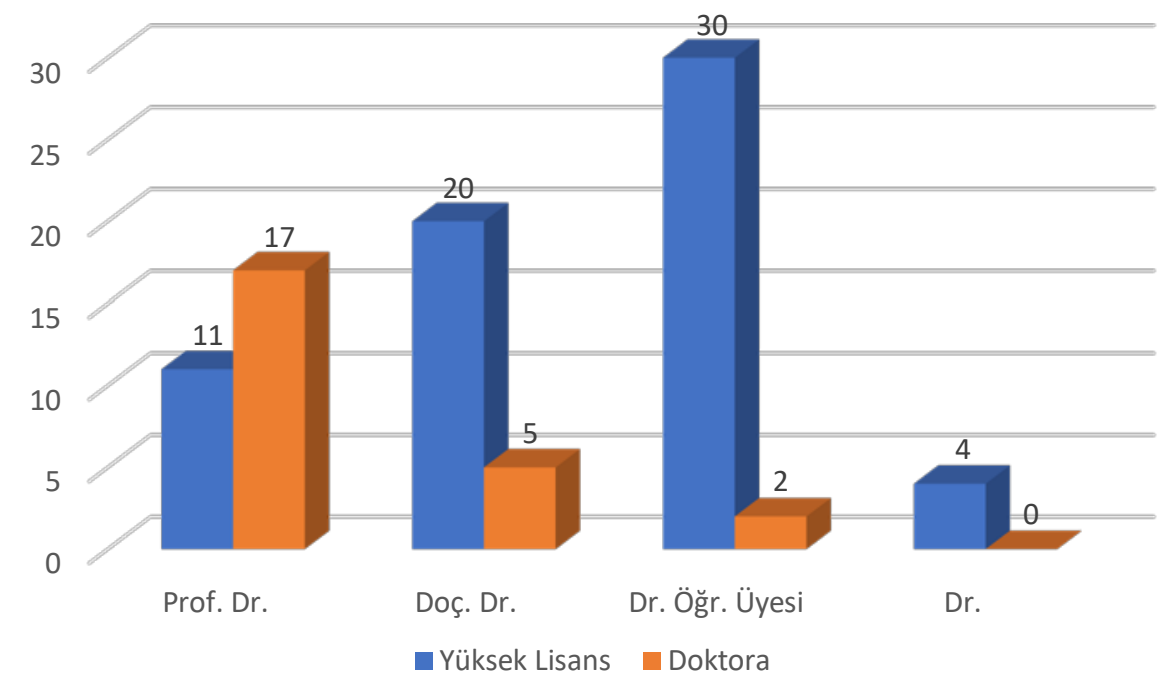

\section{Grafik 4. Danışman Unvanlarnna Göre Dağılımlar}

Grafik 4 incelendiğinde, uzamsal yetenek ile ilgili yapılmış olan doktora tezlerinin çoğunlukla profesör ( $f=17)$, yüksek lisans tezlerinin ise ağırlıklı olarak doktor öğretim üyesi ( $\mathrm{f}=30$ ) danışmanlığında gerçekleştirildiği görülmektedir. Toplamda en fazla lisansüstü tez doktor öğretim üyesi ( $\mathrm{f}=32$ ) danışmanlığında gerçekleştirilmiştir.

Uzamsal yetenek ile ilgili yapılmış olan lisansüstü tezlerin gerçekleştirildiği üniversitelere göre dağılımlarına Grafik 5 'te yer verilmiştir. 


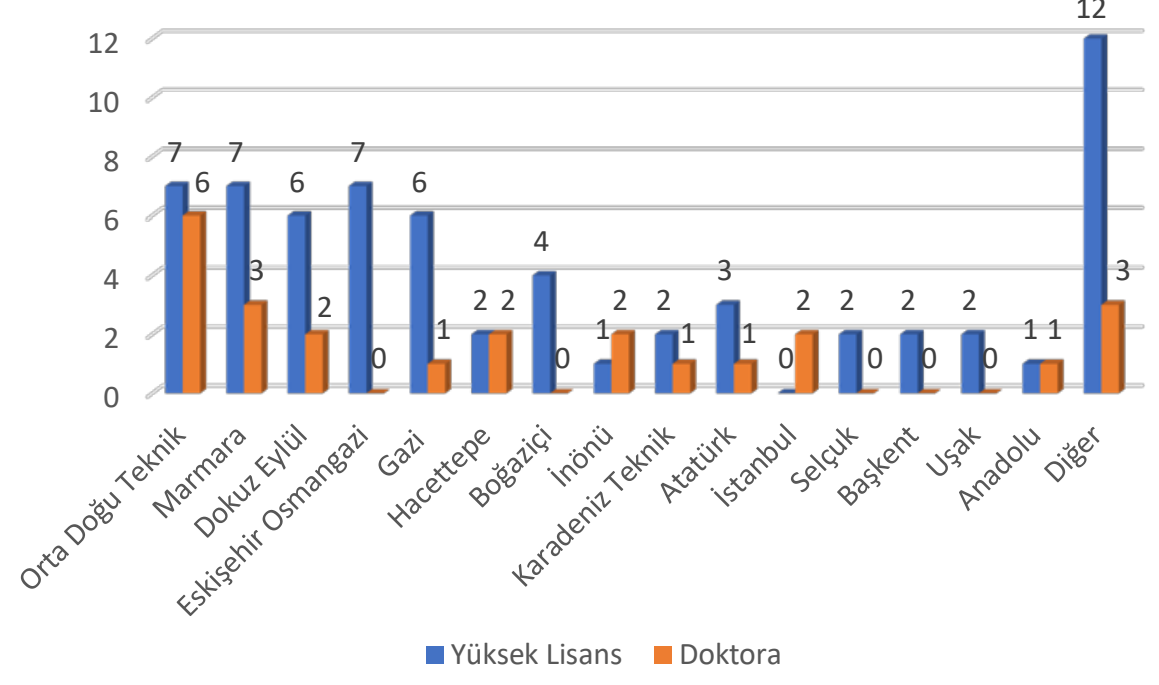

Grafik 5. Üniversitelere Göre Dă̆ılımlar

Grafik 5'teki uzamsal yetenek ile ilgili yapılmış olan lisansüstü tezlerin gerçekleştirildiği üniversitelere göre dağılımları incelendiğinde, tezlerin 30 farklı üniversitede yürütüldügü görülmektedir. Yüksek lisans tezlerinin gerçekleştirildiği üniversitelerde ilk sıralarda Orta Doğu Teknik (f=7), Marmara $(\mathrm{f}=7)$ ve Eskişehir Osmangazi ( $\mathrm{f}=7)$; doktora tezlerinin yürütüldüğ ü üniversitelerde ilk siralarda ise Orta Doğu Teknik ( $\mathrm{f}=6$ ), Marmara $(\mathrm{f}=3$ ) ve Dokuz Eylül ( $\mathrm{f}=2)$ üniversitelerinin olduğu dikkat çekmektedir. Buna göre, lisansüstü tezlerin üniversiteler arası dağılımında toplamda ilk sırayı Orta Doğu Teknik $(\mathrm{f}=13)$ ve Marmara $(\mathrm{f}=10)$ üniversitelerinin aldığ 1 saptanmıştır.

Grafik 5 'te diğer olarak belirtilen on iki yüksek lisans tezi Kastamonu $(\mathrm{f}=1)$, Recep Tayyip Erdoğan (f=1), Gaziantep ( $\mathrm{f}=1)$, Sakarya ( $\mathrm{f}=1$ ), Abant İzzet Baysal ( $f=1)$, Bülent Ecevit ( $f=1)$, Kırıkkale ( $f=1)$, Erciyes ( $f=1)$, Bilkent ( $f=1)$, Balıke$\operatorname{sir}(\mathrm{f}=1)$, Uludağ $(\mathrm{f}=1)$, Muğla Sttkı Koçman $(\mathrm{f}=1)$; üç doktora tezi ise Dicle $(\mathrm{f}=1)$, Mustafa Kemal $(\mathrm{f}=1)$, Necmettin Erbakan ( $\mathrm{f}=1)$ üniversitelerinde yapılmiştır.

Uzamsal yetenek ile ilgili yapılmış olan lisansüstü tezlerin gerçekleştirildiği enstitülere göre dağılımlar Grafik 6'da verilmiştir. 


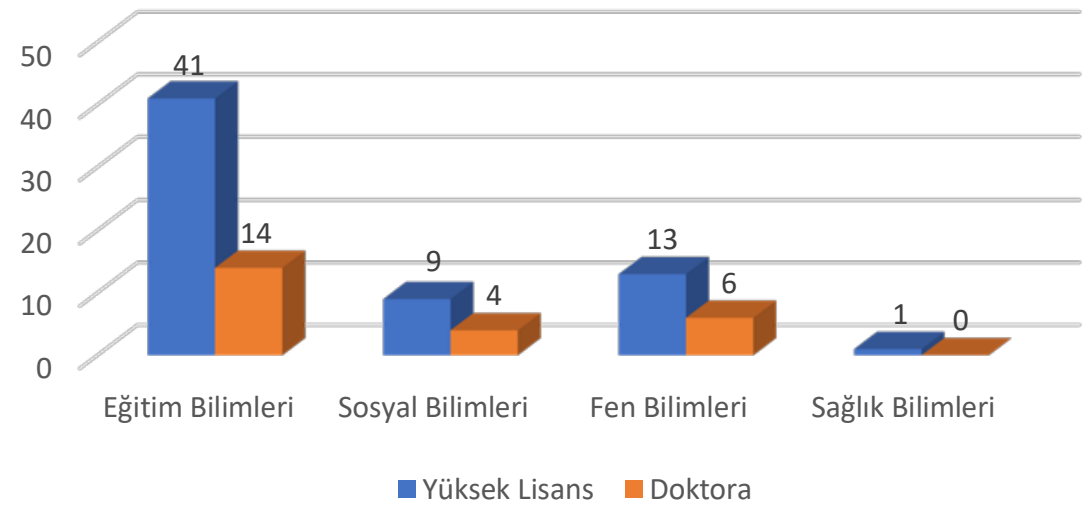

\section{Grafik 6. Enstitülere Göre Dağılımlar}

Grafik 6'da, uzamsal yetenek ile ilgili yapılmış olan yüksek lisans tezlerinin en fazla eğitim bilimleri ( $\mathrm{f}=41$ ) ve fen bilimleri ( $\mathrm{f}=13)$; benzer şekilde doktora tezlerinin de en fazla eğitim bilimleri $(\mathrm{f}=14)$ ve fen bilimleri $(\mathrm{f}=6)$ enstitülerinde yapıldığı görülmektedir. Dolayısıyla genel toplamda en fazla lisansüstü tez eğitim bilimleri ( $f=55)$ ve fen bilimleri $(f=19)$ enstitülerinde yapılmıştir.

Uzamsal yetenek ile ilgili yapılmış olan lisansüstü tezlerin gerçekleştirildiği anabilim dallarına göre dağılımlarına Grafik 7'de yer verilmiştir.

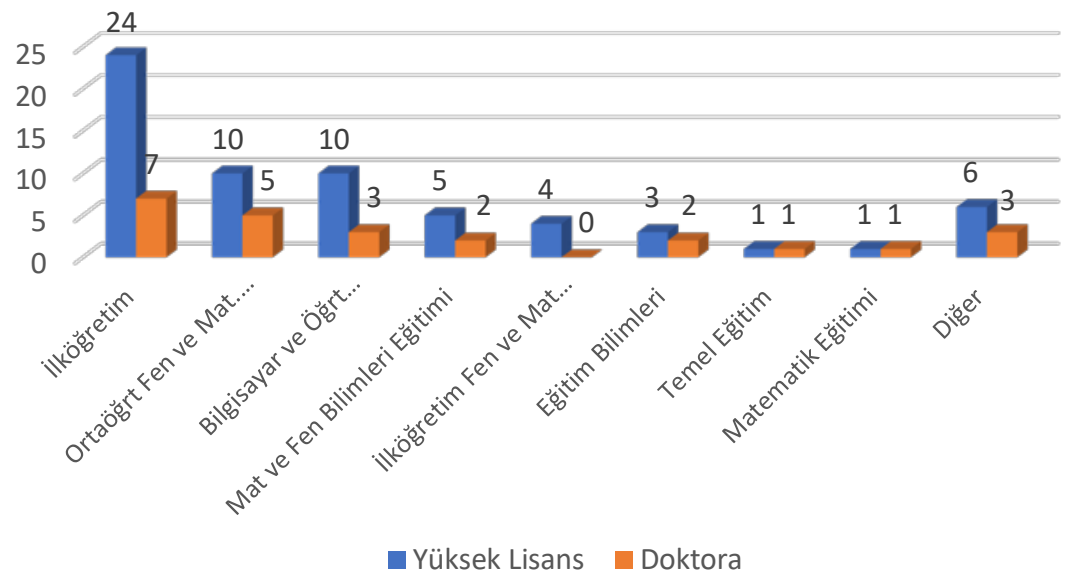

Grafik 7. Anabilim Dallarına Göre Dağılımlar 
Grafik 7'deki uzamsal yetenek ile ilgili yapılmış olan lisansüstü tezlerin gerçekleştirildiği anabilim dallarına göre dağılımları incelendiğinde, tezlerin 17 farklı anabilim dalında yürütüldüğü görülmektedir. Yüksek lisans tezlerinin önemli bir kısmı İlköğretim (f=24), Ortaöğretim Fen ve Matematik Alanları Eğitimi ( $\mathrm{f}=10)$ ve Bilgisayar ve Öğretim Teknolojileri Eğitimi ( $\mathrm{f}=10)$; benzer şekilde doktora tezlerinin büyük bir kısmı da İlköğretim (f=7), Ortaöğretim Fen ve Matematik Alanları Eğitimi (f=5) ve Bilgisayar ve Öğretim Teknolojileri Eğitimi ( $\mathrm{f}=3$ ) anabilim dallarında yapıldığı görülmektedir. Genel toplamda en fazla lisansüstü tez İlköğretim (f=31), Ortaöğretim Fen ve Matematik Alanları Eğitimi ( $f=15)$ ve Bilgisayar ve Öğretim Teknolojileri Eğitimi $(\mathrm{f}=13)$ anabilim dallarında yapılmıştır.

Grafik 7' de diğer olarak belirtilen altı yüksek lisans tezi Sınıf Eğitimi $(f=1)$, Eğitim Programları ve Öğretim (f=1), Bilgisayar Mühendisliği (f=1), İlköğretim Matematik Eğitimi ( $f=1)$, Beden Eğitimi ve Spor ( $f=1)$, Ortaöğretim Matematik Öğretmenliği ( $f=1)$; üç doktora tezi ise Üstün Zekâlılar Eğitimi $(f=1)$, Özel Eğitim ( $\mathrm{f}=1$ ), Enformatik ( $\mathrm{f}=1$ ) anabilim dallarında yapılmıştır.

Uzamsal yetenek ile ilgili yapılmış olan lisansüstü tezlerin amaçlarına göre dağılımlarına Grafik 8'de yer verilmiştir.

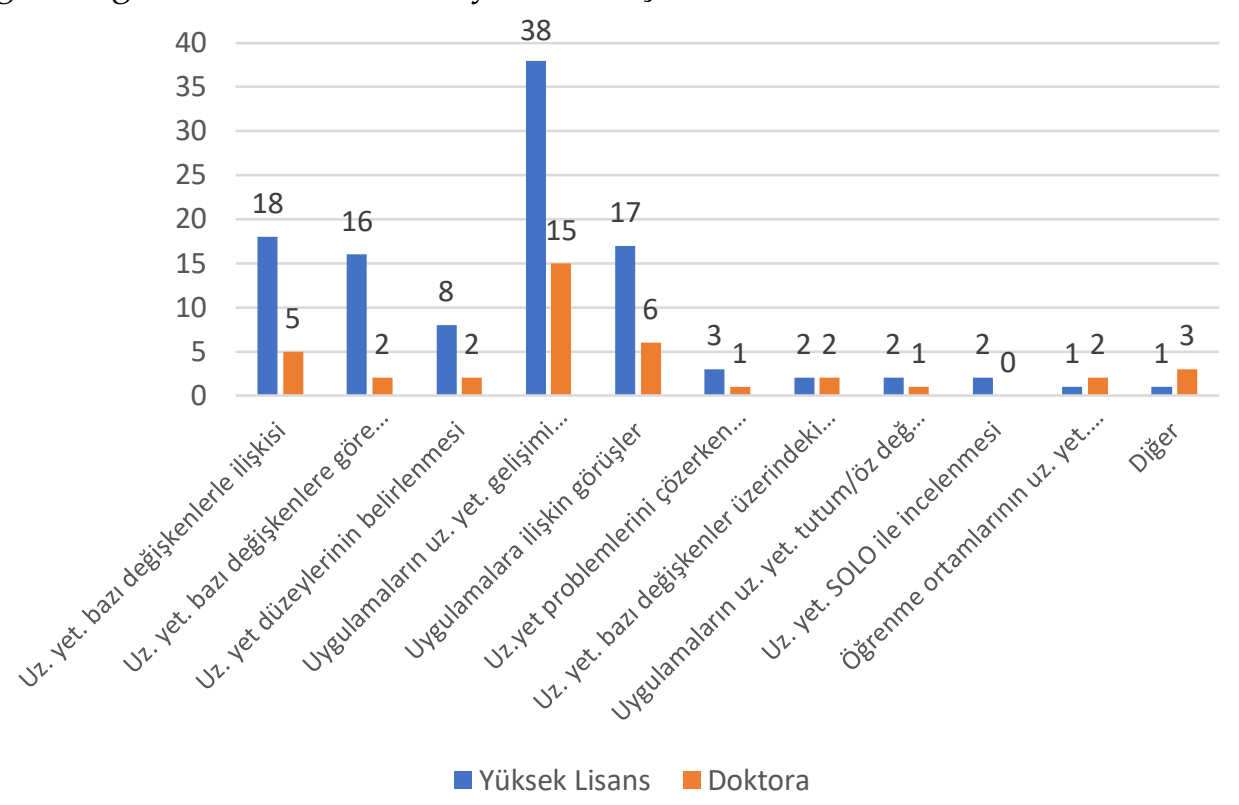

Grafik 8. Amaçlara Göre Dağılımlar 
Grafik 8'de görüldüğü üzere uzamsal yetenek ile ilgili yapılmış olan yüksek lisans tezlerinin çoğunda "farklı uygulamaların uzamsal yeteneğin gelişimi üzerindeki etkileri ( $\mathrm{f}=38)^{\prime}$ ", "uzamsal yeteneğin bazı değişkenlerle ilişkisi $(\mathrm{f}=18)$ ", "uygulamalara ilişkin görüşler $(\mathrm{f}=17)$ ", "uzamsal yeteneğin bazı değişkenlere göre incelenmesi ( $\mathrm{f}=16)$ "; doktora tezlerinin çoğunda ise "farklı uygulamaların uzamsal yeteneğin gelişimi üzerindeki etkileri ( $\mathrm{f}=15)$ ", "uygulamalara ilişkin görüşler $(\mathrm{f}=6)$ ", "uzamsal yeteneğin bazı değişkenlerle ilişkisi $(\mathrm{f}=5)$ " amaçlanmıştır. Genel toplamda lisansüstü tezlerde en fazla "farklı uygulamaların uzamsal yeteneğin gelişimi üzerindeki etkileri ( $f=53)$ " "uzamsal

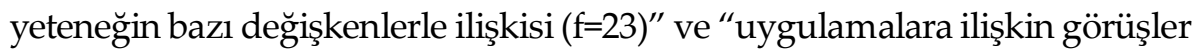
$(\mathrm{f}=23)^{\prime \prime}$ araştırılmıştır.

Grafik 8' de diğer olarak belirtilen bir yüksek lisans tezinde "zihnin uzamsal alışkanlıkları ölçeğinin Türkçe'ye uyarlanması ( $\mathrm{f}=1)^{\text {"); }}$ üç doktora tezinde ise "arttırılmış gerçeklik tabanlı bir öğretim tasarımı ve geliştirilmesi $(\mathrm{f}=1)$ ", "geometrik ve uzamsal beceriler testi ve gözlem formunun geliştirilmesi $(\mathrm{f}=1)^{\prime}$, “Uzamsal yetenek ve bileşenleri $(\mathrm{f}=1)^{\prime}$ " amaçlar arasında yer almaktadir.

Uzamsal yetenek ile ilgili yapılmış olan lisansüstü tezlerde kullanılan araştırma yöntemlerine göre dağ 1 lımlar Grafik 9' da verilmiştir.

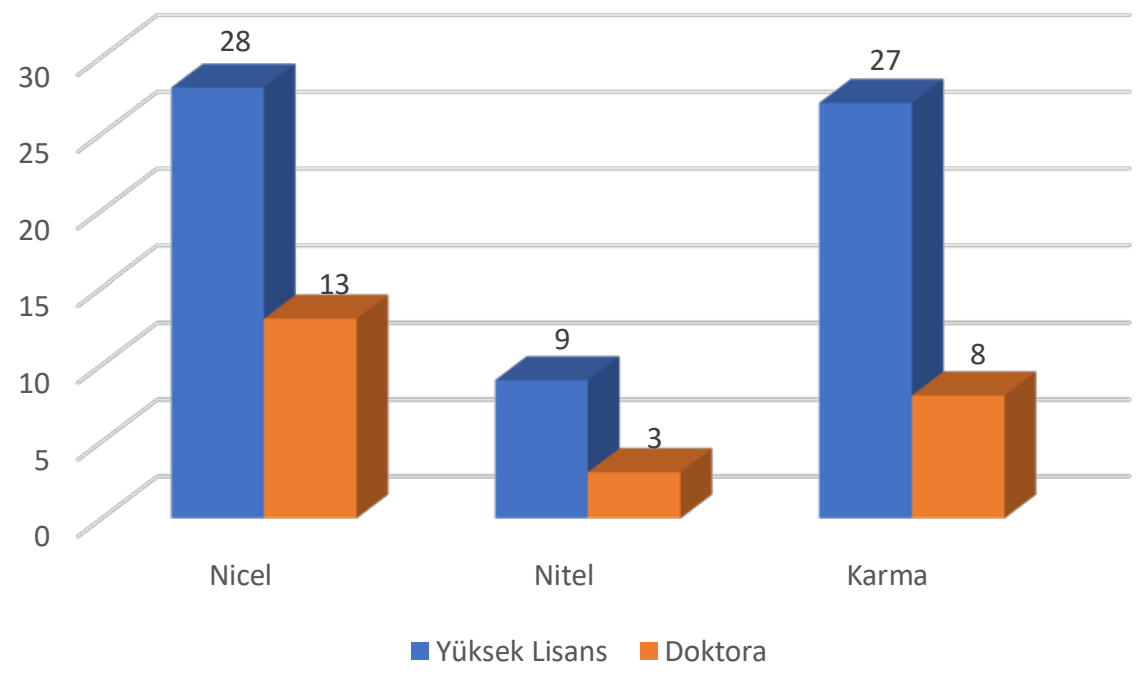

Grafik 9. Araştırma Yöntemlerine Göre Dağılımlar 
Grafik 9'a göre, uzamsal yetenek ile ilgili yapılmış olan yüksek lisans tezlerinde en fazla nicel ( $\mathrm{f}=28$ ) ve karma $(\mathrm{f}=27)$; benzer şekilde doktora tezlerinde de en fazla nicel ( $f=13)$ ve karma $(f=8)$ araştırma yönteminin tercih edildiği görülmektedir. Genel toplamda nicel $(\mathrm{f}=41)$ ve karma $(\mathrm{f}=33)$ araştırma yöntemi bu alanda yapılan lisansüstü tezlerde en fazla tercih edilen araştırma yöntemi olmuştur.

Uzamsal yetenek ile ilgili yapılmış olan lisansüstü tezlerde kullanılan araştırma desenlerine göre dağılımlar Grafik 10'da verilmiştir.

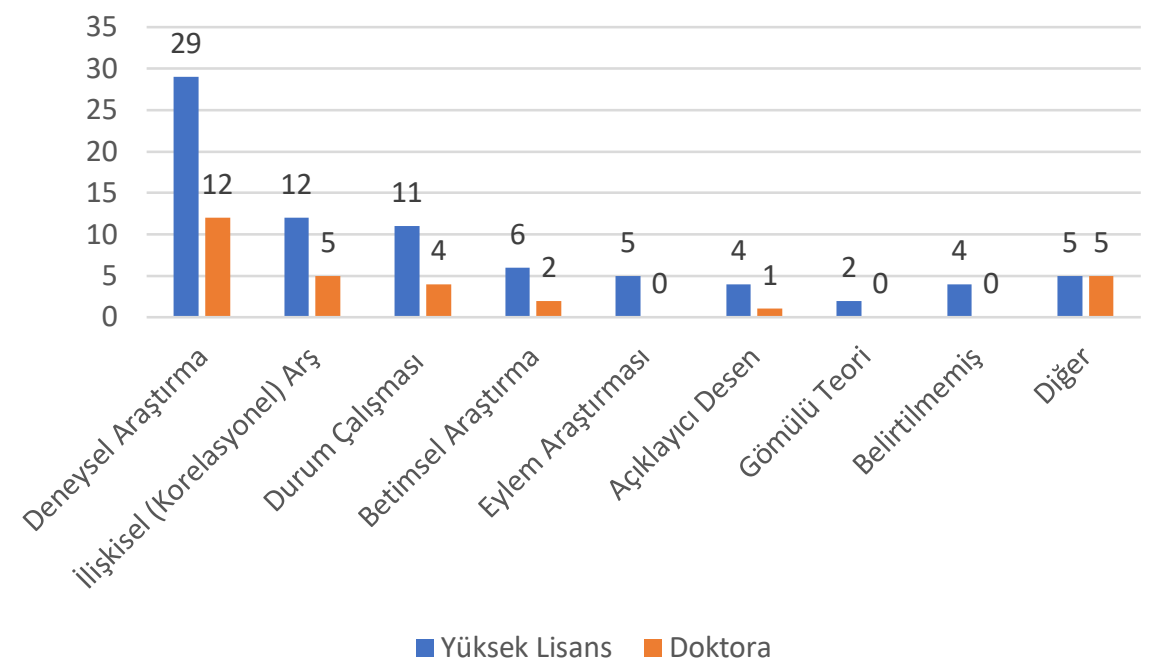

\section{Grafik 10. Araștırma Desenlerine Göre Dağıllmlar}

Grafik 10 incelendiğinde, uzamsal yetenek ile ilgili yapılmış olan yüksek lisans tezleri çoğunlukla deneysel $(\mathrm{f}=29)$, ilişkisel (korelasyonel) $(\mathrm{f}=12)$ ve durum çalışması ( $\mathrm{f}=11$ ); benzer şekilde doktora tezleri de deneysel $(\mathrm{f}=12)$, ilişkisel (korelasyonel) $(\mathrm{f}=5)$ ve durum çalışması $(\mathrm{f}=4)$ deseninde gerçekleştirildiği görülmektedir. Genel toplamda deneysel desenin ( $f=41$ ) uzamsal yetenek ile ilgili yapılmış olan lisansüstü tezlerde en fazla tercih edilen desen olduğu ortaya çıkmıştır. Bununla birlikte yüksek lisans tezlerinin bir kısmının ( $\mathrm{f}=4)$ kullandıkları araştırma desenini tezde belirtmedikleri de dikkat çekmektedir.

Grafik 10'da diğer olarak belirtilen beş yüksek lisans tezi olgu bilim (fenomenografik) $(\mathrm{f}=1)$, doküman inceleme $(\mathrm{f}=1)$, müdahale deseni $(\mathrm{f}=1)$, siralı açıklayıcı tasarım ( $f=1)$, nedensel karşılaştırmalı araştırma ( $f=1)$ desenlerinde; 
beş doktora tezi ise eğitsel tasarım ( $\mathrm{f}=1)$, tasarım tabanlı araştırma $(\mathrm{f}=1)$, yakınsak paralel ( $\mathrm{f}=1)$, gömülü desen $(\mathrm{f}=1)$, kesitsel araştırma $(\mathrm{f}=1)$ desenlerinde yapılmıştır.

Uzamsal yetenek ile ilgili yapılmış olan lisansüstü tezlerde üzerinde çalışılan örneklem gruplarına göre dağılımlar Grafik 11'de verilmiştir.

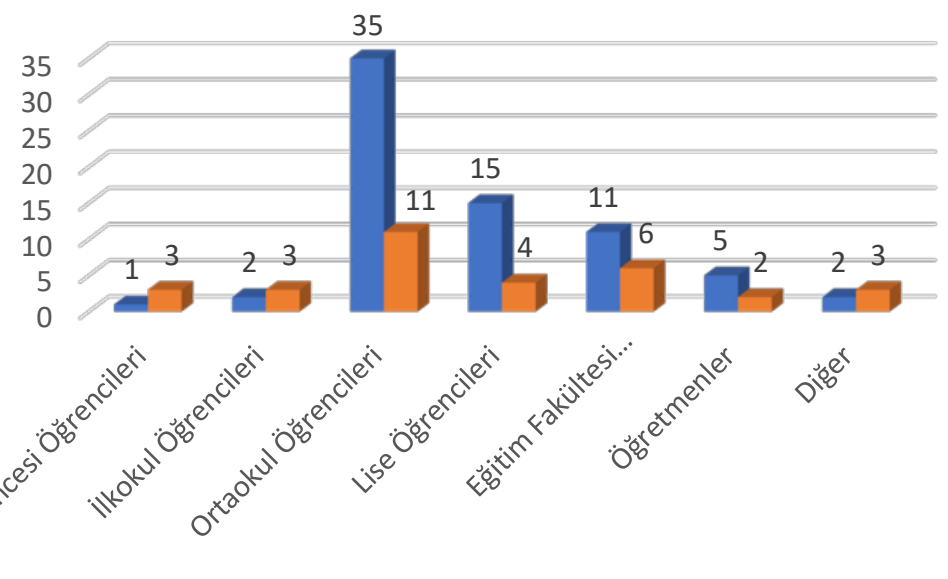

- Yüksek Lisans noktora

\section{Grafik 11. Örneklem Gruplarına Göre Dağılımlar}

Grafik 11'e göre, uzamsal yetenek ile ilgili yapılmış olan yüksek lisans tezlerinde ağırlıklı olarak ortaokul ( $\mathrm{f}=35)$, lise ( $\mathrm{f}=15$ ) ve eğitim fakültesi öğrencileri $(\mathrm{f}=11)$; doktora tezlerinde ise ortaokul $(\mathrm{f}=11)$, eğitim fakültesi $(\mathrm{f}=6)$ ve lise öğrencileri ( $\mathrm{f}=4)$ ile çalışıldığı görülmektedir. Genel toplamda lisansüstü tezlerde en fazla ortaokul öğrencileri $(\mathrm{f}=46)$ ile çalışılmıştır.

Grafik 11 'de diğer olarak belirtilen iki yüksek lisans tezinde mühendislik fakültesi öğrencileri ( $f=1$ ), mesleki eğitime devam eden öğrenciler ( $f=1$ ); üç doktora tezinde ise tıp fakültesi öğrencileri $(\mathrm{f}=1)$, matematik eğitimi uzmanı $(\mathrm{f}=1)$, ebeveynler $(\mathrm{f}=1)$ ile çalışılmıştır.

Uzamsal yetenek ile ilgili yapılmış olan lisansüstü tezlerde yararlanılan örnekleme yöntemlerine göre dağılımlara Grafik 12' de yer verilmiştir. 


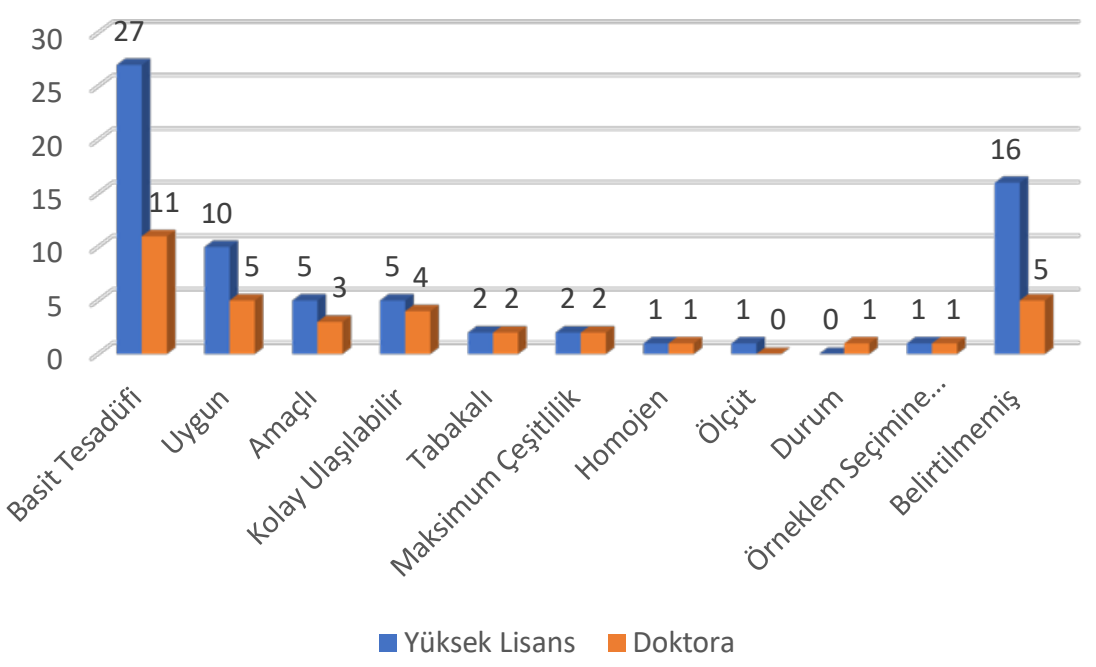

\section{Grafik 12. Örnekleme Yöntemlerine Göre Dağılımlar}

Grafik 12 incelendiğinde, uzamsal yetenek ile ilgili yapılmış olan yüksek lisans tezlerinde ilk sıralarda basit tesadüfî ( $\mathrm{f}=27$ ) ve uygun ( $\mathrm{f}=10)$; benzer şekilde doktora tezlerinde de basit tesadüfî ( $\mathrm{f}=11$ ) ve uygun ( $\mathrm{f}=5$ ) örnekleme yöntemlerinin kullanıldığı görülmektedir. Genel toplamda basit tesadüfî örnekleme yönteminin ( $\mathrm{f}=38$ ) uzamsal yetenek ile ilgili yapılmış olan lisansüstü tezlerde en fazla tercih edilen örnekleme yöntemi olduğu ortaya çıkmıştır. Örneklem seçimine gitmeyen yüksek lisans ( $\mathrm{f}=1$ ) ve doktora tezleri $(\mathrm{f}=1) \mathrm{de}$ mevcuttur. Bununla birlikte yüksek lisans ve doktora tezlerinin önemli bir kısmının ( $\mathrm{f}=21)$ kullandıkları örnekleme yöntemlerini tezde belirtmemeleri dikkat çekici bulunmuştur.

Uzamsal yetenek ile ilgili yapılmış olan lisansüstü tezlerde tercih edilen örneklem büyüklüklerine göre dağılımlar Grafik 13 'te verilmiştir. 


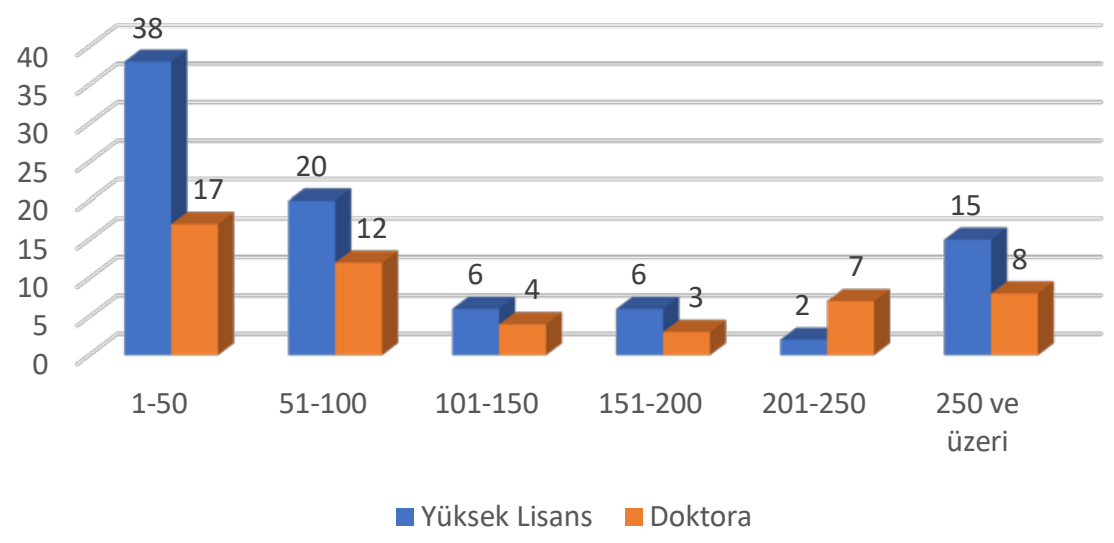

\section{Grafik 13. Örneklem Büyüklüklerine Göre Dağılımlar}

Grafik 13 incelendiğinde uzamsal yetenek ile ilgili yapılmış olan yüksek lisans tezlerinin büyük bir kısmında 1-50 ( $\mathrm{f}=38)$ ve $51-100(\mathrm{f}=20)$; benzer şekilde doktora tezlerinin büyük bir kısmında da 1-50 ( $\mathrm{f}=17)$ ve 51-100 ( $\mathrm{f}=12)$ kişilik örneklem büyüklüğünün tercih edildiği görülmektedir. Genel toplamda uzamsal yetenek ile ilgili yapılmış olan lisansüstü tezlerde en fazla 150 (f=55) ve 51-100 ( $\mathrm{f=32}$ ) kişilik örneklem büyüklüğü tercih edilmiştir.

Uzamsal yetenek ile ilgili yapılmış olan lisansüstü tezlerde kullanılan veri toplama araçlarına göre dağılımlara Grafik 14 'te yer verilmiştir.

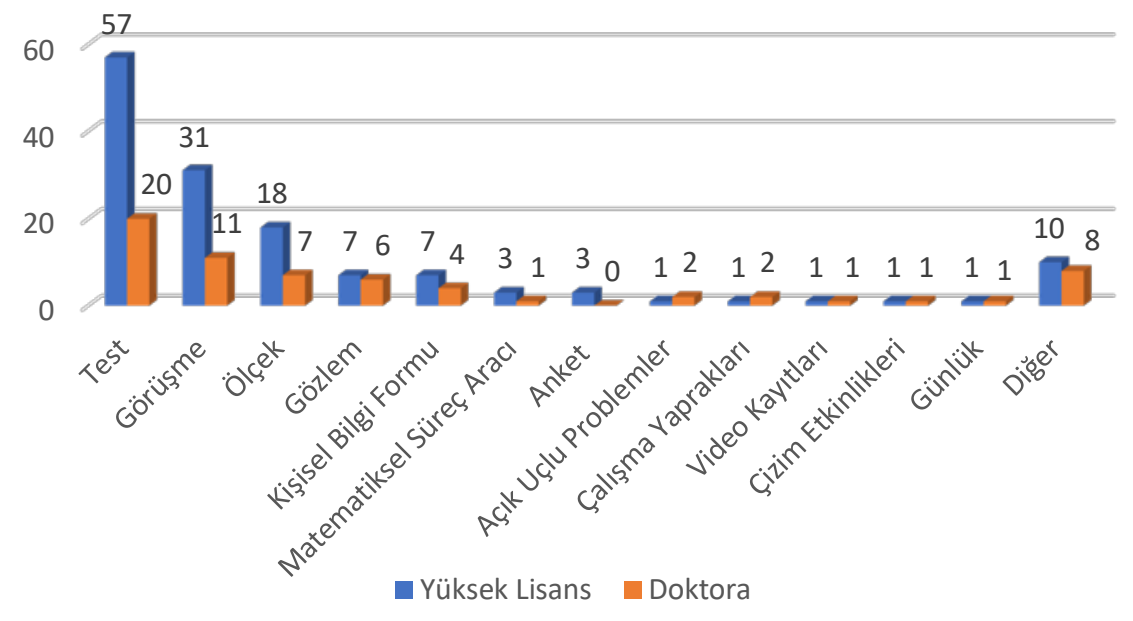

Grafik 14. Veri Toplama Araçlarna Göre Dağılımlar 
Grafik 14 'te, uzamsal yetenek ile ilgili yapılmış olan lisansüstü tezlerde birçok farklı veri toplama aracından yararlanıldığı görülmektedir. Bu alanda yapılmış yüksek lisans tezlerinde ilk sıralarda test $(\mathrm{f}=57)$, görüşme $(\mathrm{f}=31)$, ölçek $(\mathrm{f}=18)$; benzer şekilde doktora tezlerinde de test $(\mathrm{f}=20)$, görüşme $(\mathrm{f}=11)$, ölçek ( $\mathrm{f}=7$ ) gibi veri toplama araçlarından yararlanılmıştır. Genel toplamda testin ( $\mathrm{f}=77$ ) uzamsal yetenek ile ilgili yapılmış olan lisansüstü tezlerde en fazla tercih edilen veri toplama aracı olduğu belirlenmiştir.

Grafik 14 'te diğer olarak belirtilen on yüksek lisans tezinde veri toplama aracı olarak modelleme etkinlikleri ( $\mathrm{f}=1)$, envanter $(\mathrm{f}=1)$, rubrik ( $\mathrm{f}=1)$, fiziksel modeller $(\mathrm{f}=1)$, etkinlik kağıtları $(\mathrm{f}=1)$, yansitma raporu $(\mathrm{f}=1)$, fotoğraf $(\mathrm{f}=1)$, yazılı değerlendirme soruları $(\mathrm{f}=1)$, dikkate alıyorum formu $(\mathrm{f}=1)$, sorular $(\mathrm{f}=1)$; sekiz doktora tezinde ise eskiz $(\mathrm{f}=1)$, yazılı notlar $(\mathrm{f}=1)$, sanat çalışmaları $(\mathrm{f}=1)$, matematiksel sorular $(\mathrm{f}=1)$, araştırmacı-öğretmen alan notları $(\mathrm{f}=1)$, elektronik kontrol sistemi ( $\mathrm{f}=1)$, bireysel-grup içi ürünler $(\mathrm{f}=1)$, geometrik şekilleri tanıma formu $(\mathrm{f}=1)$ kullanılmıştır.

Uzamsal yetenek ile ilgili yapılmış olan lisansüstü tezlerde kullanılan veri analiz tekniklerine göre dağllımlara Grafik $15^{\prime}$ te yer verilmiştir.

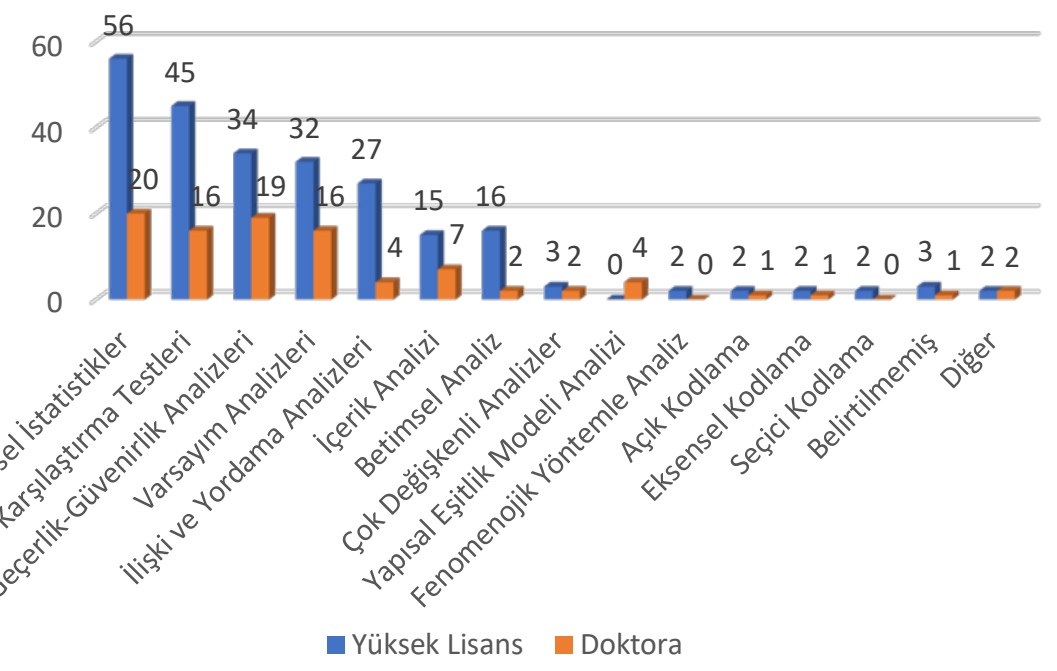

Grafik 15. Veri Analiz Tekniklerine Göre Dă̆glımlar

Grafik 15 'te uzamsal yetenek ile ilgili yapılmış olan yüksek lisans tezlerinin çoğunda kullanılan veri analiz tekniklerinin sırasıyla betimsel istatistikler 
$(\mathrm{f}=56)$, karşılaştırma testleri ( $\mathrm{f}=45)$, geçerlik-güvenirlik analizleri ( $\mathrm{f}=34)$, varsayım analizleri ( $\mathrm{f}=32)$; doktora tezlerinin çoğunluğunda kullanılan veri analiz tekniklerinin ise sırasıyla betimsel istatistikler $(\mathrm{f}=20)$, geçerlik-güvenirlik analizleri ( $\mathrm{f}=19)$, karşılaştırma testleri $(\mathrm{f}=16)$ ve varsayım analizleri $(\mathrm{f}=16)$ olduğu görülmektedir. Genel toplamda betimsel istatistikler ( $\mathrm{f}=76$ ) tekniğinin uzamsal yetenek ile ilgili yapılmış olan lisansüstü tezlerde en fazla tercih edilen veri analiz tekniği olduğu ortaya çıkmıştır. Bununla birlikte lisansüstü tezlerinin bir kısmının ( $\mathrm{f}=4$ ) kullandıkları veri analiz tekniğini tezde belirtmedikleri görülmektedir.

Grafik 15 'te diğer olarak belirtilen iki yüksek lisans tezinde veri analiz tekniği olarak söylem analizi $(\mathrm{f}=1)$, doküman analizi $(\mathrm{f}=1)$; iki doktora tezinde ise "sürekli karşılaştırmalı analiz (f=1), kavramsal analiz (f=1) kullanılmıştır.

\section{Tartışma ve Sonuç}

Ülkemizde 1996-2020 yılları arasında uzamsal yetenek ile ilgili yapılan lisansüstü tezlerin incelenmesi amacıyla yapılan bu araştırmada, Yükseköğretim Kurulu Tez Dokümantasyon Merkezine kayıtlı 88 lisansüstü tez incelenmiştir. Bu tezlerin çoğunu yüksek lisans tezi oluşturmaktadır. Bu durumun, üniversitelerin çoğunluğunun yüksek lisans düzeyinde lisansüstü eğitim vermesinden ve üniversitelerin doktora programlarını açma kriterlerini karşılayamamalarından kaynaklandığı söylenebilir. Doktora eğitimine giriş koşullarının ağır ve doktora eğitiminin yüksek lisans eğitim sürecine oranla daha zor olması bu bulgunun başka bir nedeni olarak gösterilebilir. Bununla birlikte, uzamsal yetenek ile ilgili yapılmış olan lisansüstü tezler genellikle Türkçe yazılmış ve tezlerin sayısında son yıllarda artış olmuştur. Yüksek lisans tezleri en çok 2016 ve 2018; doktora tezleri ise en çok 2012, 2017 ve 2019 yıllarında gerçekleştirilmiştir. 1997-2004 yılları arasında yüksek lisans tezi, 1996-2009 yılları arasında ise doktora tezi yapılmamıştı. Uzamsal yetenek ile ilgili doktora tezi ilk olarak 2010 yılında yapılmıştır. Toplamda en fazla lisansüstü tez 2019 yılında yapılmıştır. Uzamsal yetenek ile ilgili yapılmış olan doktora tezleri çoğunlukla profesör, yüksek lisans tezleri ise doktor öğretim üyesi danışmanlığında gerçekleştirilmiştir. Toplamda en fazla lisansüstü tez doktor öğretim üyesi danışmanlığında gerçekleştirilmiş̧ir. 
Uzamsal yetenek ile ilgili yapılmış olan lisansüstü tezlerin gerçekleştirildiği üniversitelere göre dağılımları incelendiğinde, tezler 30 farklı üniversitede yürütülmüştür. Yüksek lisans tezlerinin gerçekleştirildiği üniversitelerde ilk sıralarda Orta Doğu Teknik, Marmara ve Eskişehir Osmangazi; doktora tezlerinin yürütüldüğü üniversitelerde ilk sıralarda ise Orta Doğu Teknik, Marmara ve Dokuz Eylül üniversitelerinin olduğu dikkat çekmektedir. Buna göre, lisansüstü tezlerin üniversiteler arası dağılımında toplamda ilk s1raları Orta Doğu Teknik ve Marmara üniversitelerinin aldığı saptanmıştır. Bu bulgu, bu üniversitelerin sahip olduğu tarihsel ve kurumsal misyon ile açıklanabilir. Ayrıca bu bulgunun nedeni, bu üniversitelerde lisansüstü tezlere danışmanlık yapan öğretim elemanlarının uzamsal yetenek ile ilgili yeterli kuramsal bilgiye sahip olması, bu konuda çalışmaları olması dolayısıyla da danışmanlık yaptığı öğrencilerini de bu konuda tez yapmaları için yönlendirmesi olabilir. Bununla birlikte uzamsal yetenek ile ilgili yapılmış olan hem yüksek lisans hem de doktora tezleri en fazla eğitim bilimleri ve fen bilimleri enstitülerinde yapılmıştır. Yüksek lisans ve doktora tezlerinin önemli bir kısmı İlköğretim, Ortaöğretim Fen ve Matematik Alanları Eğitimi, Bilgisayar ve Öğretim Teknolojileri Eğitimi anabilim dallarında yapılmıştır. Bu durum, bu alanların uzamsal yetenekle doğrudan ilişkili olması ile açıklanabilir. Çünkü uzamsal yetenek fen (science), teknoloji (technology), mühendislik (engineering) ve matematik (mathematics) alanları (STEM) için oldukça önem bir yere sahiptir (Lubinski, 2010; Uttal ve Cohen, 2012; Young, Cartmill, Levine ve Goldin-Meadow, 2014). Bu gibi alanlarda başarılı olabilmek için gerekli olan uzamsal yetenek doğuştan, dil ve diğer özelleşmiş yetenekler ile birlikte, kalıtsal yetenekler ve deneyim arasındaki etkileşimler yoluyla gelişmektedir (Mathewson, 1999). Osberg (1997), bir çocuğun dünyada var olan ya da kendi zihninde yarattı̆̆ imgeleri manipüle ederek anlam yaratmasına izin veren uzamsal yeteneğin eksikliği durumunda, okul çevresinde ve muhtemelen günlük yaşamında da zorluk çekeceğini ve bu nedenle küçük yaşlardan itibaren uzamsal yeteneğin nasıl geliştirilebileceği ve sürdürülebileceği konusuna önem verilmesi gerektiğini ifade etmiştir. Nitekim uzamsal yetenek ile ilgili yapılan lisansüstü tezlerde de en çok uzamsal yeteneğin geliştirilmesi üzerine odaklanılmıştır. Lisansüstü tezlerde uzamsal yeteneğin nasıl geliştirileceği ile ilgili araştırmacılar farklı iddiaları ileri sürmüşlerdir. Araştırmacıların uzamsal yeteneği geliştirebileceğini iddia ettikleri uygulamalardan bazıları somut materyaller, sanal ortamlar, bilgisayar yazılımları, zeka 
oyunları, origami tabanlı öğretim, Sketchup uygulamaları, arttırılmış gerçeklik uygulamaları, teknik resim dersi, dijital oyunlar, oryantiring eğitimi, google earth, farklılaştırılmış geometri öğretimidir. Bununla birlikte lisansüstü tezlerde uygulamalara ilişkin görüşler ve uzamsal yeteneğin bazı değişkenler (akademik başarı, mantıksal düşünme yeteneği, geometriye yönelik öz-yeterlik algısı, geometrik düşünme düzeyi, geometri bilgileri, problem çözme becerileri, uzamsal kaygı) ile ilişkileri de sıklıkla araştırılmıştır.

Bilimsel araştırmaların en önemli hususlarından biri yöntem konusudur. Bir araştırmaya başlamadan önce ilk olarak yapılması gereken yöntemin belirlenmesidir. Sosyal ve beşeri bilimlerde nicel ve nitel yönteme ek olarak son yıllarda kullanımı artan, her iki tür veri toplama şeklini kullanan karma yöntem araştırmaları mevcuttur (Baki ve Gökçek, 2012). Uzamsal yetenek ile ilgili yapılmış olan lisansüstü tezlerde en fazla nicel ve karma araştırma yöntemleri tercih edilmiştir. Genel toplamda nicel araştırma yöntemi bu alanda yapılan lisansüstü tezlerde en fazla tercih edilen araştırma yöntemi olmuştur. Uzamsal yetenek ile ilgili yapılmış olan tezlerde daha çok tercih edilen yöntemin nicel yöntem olmasının nedeni, bu tezlerin konu ve amaçları ile alakalıdır. Çünkü bir araştırmanın konu ve amacına göre yöntemi de değişiklik göstermektedir (Karasar, 2011). Ancak son ylllarda eğitim ve sosyal alanlarda nicel yöntemin tercih edildiği araştırmaların tek başına zayıf kaldığı görüşü hâkimdir (Üzümcü, 2016). Dolayısıyla az sayıda denekle derinlemesine inceleme yapmaya olanak sağlayan nitel, nitel ve nicel verileri birlikte kullantmına olanak sağlayan karma araştırmaların daha güçlü verilere ulaşmamızı sağlaması açısından son derece önemlidir (Gürdal, Bakioğlu ve Öztuna, 2010). Uzamsal yetenek ile ilgili lisansüstü tezlerde deneysel desenin yoğun olarak kullanıldığı ortaya çıkmıştır. Hem yüksek lisans hem de doktora tezlerinde en çok deneysel desenlerinin tercih edilmesi çalı̧̧malarda uzamsal yeteneğin farklı uygulamalar ile geliştirilmesi üzerine odaklanıldığı içindir. Bununla birlikte lisansüstü tezlerinin bir kısmının kullandıkları araştırma desenini tezde belirtmedikleri de dikkat çekmektedir. Oysa araştırmanın nasıl yapılacağının yöntem bölümünde ayrıntılı bir şekilde yazılması gerekmektedir (Yılmaz ve Altınkurt, 2012). Çünkü bir araştırmanın yönteminin ayrıntılı ve doğru olarak verilmesi, o araştırmadan elde edilen sonuçların doğruluğu, inandırıcıllğı ve tekrarlanabilirliği ile yakından ilişkilidir (Karasar, 2011). 
Uzamsal yetenek ile ilgili yapılmış olan hem yüksek lisans hem de doktora tezlerinde ağırlıklı olarak ortaokul, lise ve eğitim fakültesi öğrencileri ile çalışılmıştır. Bu bulguya göre uzamsal yetenek ile ilgili yapılmış olan lisansüstü tezlerde çalışlan örneklem gruplarında, öğrencilerin gelişim özelliklerinin dikkate alındığı söylenebilir. Çünkü Piaget'e göre soyut düşünmenin başladığ1 ve hızla geliştiği dönem ilköğretim ikinci kademedir (Senemoğlu, 2012). Bu nedenle, soyut düşünme becerisi gerektiren uzamsal yetenek ile ilgili yapılacak çalışmalar için soyut işlemler döneminde olan ortaokul, lise ve üniversite öğrencilerinin seçilmesi gereklidir. Çünkü bir çalışmada eğer örneklem uygun değilse, araştırma problemi ne kadar önemli olursa olsun, takip eden aşamaların iyi tasarlanıp tasarlanmadığına bakılmaksızın yapılan araştırmadan şüphe duyulur (Erkuş, 2009). Uzamsal yetenek ile ilgili yapılmış olan hem yüksek lisans hem de doktora tezlerinde ilk suralarda basit tesadüfî (rasgele) örnekleme yöntemi kullanılmıştır. Bu durum, deneysel araştırmalarda sıklıkla kullanılan örnekleme yönteminin basit tesadüfi (rasgele) örnekleme yönteminin olması ile açıklanabilir. Gerçek deneysel desenler, birden çok grup kullanılması ve araştırmacılar tarafından sınıfların yansız atama ile oluşturulduğu durumlarda kullanılır (Karasar, 2011). Ülkemizde sinıflar daha önceden okul yönetimleri tarafından oluşturulduğundan dolayı, araştırmacıların sınıfları rastgele atama yoluyla oluşturmaları mümkün değildir. Bu nedenle yapılan araştırmalarda gerçek deneysel desenler yerine yarı deneysel desenler kullanılmakta ve var olan sinıflar rastgele deney ve kontrol grubu olarak seçilmektedir (Çepni, 2014). Her iki deneysel desende de basit tesadüfi (rasgele) örnekleme yöntemi sıklıkla kullanılması bu bulguya gerekçe olarak gösterilebilir. Örneklem seçimine gitmeyen yüksek lisans ve doktora tezleri de mevcuttur. Bununla birlikte yüksek lisans ve doktora tezlerinin önemli bir kısmı kullandıkları örnekleme yöntemlerini tezde belirtmemişlerdir. Oysa Yılmaz ve Altınkurt'a (2012) göre araştırmalar raporlaştırılırken örnekleme yöntemlerine ve veri toplama süreçlerine eksiksiz ve doğru olarak yer verilmesi, araştırmanın nasıl yapıldığına açıklık getirmek ve sonraki araştırmalara kılavuzluk etmek açısından önemlidir. Bununla birlikte uzamsal yetenek ile ilgili yapılmış olan hem yüksek lisans hem de doktora tezlerinde ilk sıralarda 1-50 ve 51-100 kişilik örneklem büyüklüğü tercih edilmiştir. Ülkemizde sınıflar daha önceden okul yönetimleri tarafından oluşturulduğundan dolayı eğitim araştırmalarında sıklıkla kullanılan yarı deneysel 
desende bir ya da daha fazla deney ve kontrol grupları var olan sinıflar arasindan rastgele seçilir (Çepni, 2014) ve diğer nicel yöntemin desenlerine göre deneysel desende daha az sayıda örneklemle çalışılır. Ülkemizde ilkokul ve ortaokullardaki sınıf mevcutlarının ortalama 20 ile 40 arasında olduğu dikkate alındığında örneklem büyüklüklerinin karşılandığı da söylenebilir.

Uzamsal yetenek ile ilgili yapılmış olan lisansüstü tezlerde nitel ve nicel olmak üzere birçok farklı veri toplama aracından yararlanıldığı görülmektedir. Bu alanda yapılmış hem yüksek lisans hem de doktora tezlerinde ilk sıralarda test, görüşme, ölçek gibi veri toplama araçlarından yararlanılmıştır. Genel toplamda testin uzamsal yetenek ile ilgili yapılmış olan lisansüstü tezlerde en fazla tercih edilen veri toplama aracı olduğu belirlenmiştir. Juodaityte ve Kazlauskine (2008), araştırma modeline, amacına ve problem cümlesine uygun olarak, kullanılacak veri toplama araçlarının seçiminin yapılması gerektiğini ifade etmişlerdir. Çoğunlukla veri toplama aracı olarak testin kullanılması, uzamsal yetenek ile ilgili yapılmış olan lisansüstü tezlerde daha fazla tercih edilen araştırma yönteminin nicel araştırma yöntemi, araştırma deseninin deneysel desen olması ile açıklanabilir. Ayrıca literatürde öğrencilerin uzamsal yetenek ve bileşenlerini ölçmek amacıyla hazırlanan kâğıt-kalem testlerinden [Purdue Uzamsal Görselleştirme Testi (Guay, 1976); MGMP Uzamsal Görselleştirme Testi (Winter, Lappan, Fitzgerald ve Shroyer, 1989); Ayrımsal Yetenek Testi (Bennett, Seashore ve Wesman, 1974); Zihinsel Döndürme Testi (Shepard ve Metzler, 1971); Nesne Döndürme Testi (Demetriou, Christou, Spanoudis ve Platsidou, 2002); French Reference Kit (Ekstrom, French ve Harman, 1976); Görüntü Perspektif Testi (Pittalis ve Christou, 2010) çok sayıda bulunması da bu bulgunun nedeni olarak gösterilebilir.

Uzamsal yetenek ile ilgili yapılmış olan yüksek lisans tezlerinin çoğunda kullanılan veri analiz tekniklerinin sırasıyla betimsel istatistikler, karşılaştırma testleri, geçerlik-güvenirlik analizleri, varsayım analizleri; doktora tezlerinin çoğunluğunda kullanılan veri analiz tekniklerinin ise sırasıyla betimsel istatistikler, geçerlik-güvenirlik analizleri, karşılaştırma testleri ve varsayım analizleri olduğu görülmektedir. Uzamsal yetenek ile ilgili yapılmış olan lisansüstü tezlerin çoğunluğu nicel yöntemle tasarlandığ için nicel veri analiz tekniklerinin sıklıkla kullanıldığı söylenebilir. Bununla birlikte betimsel istatistiklerin diğer tekniklere kıyasla en çok kullanılmasının nedeni, nicel, nitel ve karma araştırmalarda da çalışılan grupların kişisel bilgilerine yer verilirken frekans, ortalama gibi betimsel istatistiklerden yararlanılması olabilir. 
Geçerlik-güvenirlik analizlerinin sık kullanılmasının nedeni, tezlerde en çok kullanılan veri toplama aracı olan testlerin araştırmacılar tarafından geliştirilmelerinden ya da literatürde yer alan kağıt-kalem testlerinin kendi örneklemlerine uygunluğunun sınanmasından kaynaklanabilir. Varsayım testleri (normallik, homojenlik vb.) ise karşılaştırma testleri yapılmadan önce sınanması gerektiği için araştırmacılar tarafından sıklıkla kullanılmaktadır. Ancak karşılaştırma testlerinin kullanımı, varsayım analizlerinin kullanımından sayıca fazla olduğundan, bazı araştırmacıların verilere varsayım analizi yapmayıp, direkt karşılaştırma testleri yaptıkları şeklinde yorumlanabilir. Bununla birlikte lisansüstü tezlerinin bir kısmının kullandıkları veri analiz tekniğini tezde belirtmemeleri de dikkat çekmektedir. Oysa araştırmaların nasıl yapilacağının yöntem bölümünde ayrıntılı bir şekilde yazılması gerekmektedir (Yılmaz ve Altınkurt, 2012). Çünkü araştırma süreci içinde yöntemi oluşturan unsurların eksik ve yanlış ele alınması ya da bu unsurlara hiç yer verilmemesi araştırma sürecini olumsuz etkileyecektir (Erkuş, 2009).

İncelenen lisansüstü tezlerde belli başlı araştırma yöntemleri, araştırma desenleri, örneklem grupları, örnekleme yöntemleri, örneklem büyüklükleri, veri toplama araçları ve veri analiz yöntemlerinin sıklıkla kullanıldığı ortaya çıkmıştır. Bu nedenle ileride yapılacak uzamsal yetenekle ilgili çalışmalarda sıklıkla kullanılan nicel yöntem yerine derinlemesine bilgi edinilmesi amacıyla nitel ya da karma araştırma yöntemlerine yer verilebilir. Sık kullanılan araştırma desenlerinin ve veri toplama araçlarının yerine daha az tercih edilen farklı araştırma desenlerine ve veri toplama araçlarına yer verilmesi önerilebilir. Bunun yanında veri analiz yöntemlerin çeşitlendirilmesine ve ileri düzey istatistik ve analiz tekniklerinin kullanılması da önerilebilir. 


\title{
EXTENDED ABSTRACT
}

\section{Research Tendencies towards Spatial Ability in Turkey \\ *}

\author{
Neşe Dokumacı Sütçü \\ Dicle University
}

In this research, it was aimed to determine the research tendencies towards spatial ability between 1996-2020 in Turkey. In accordance with this purpose, the types, languages, years, titles of advisors, conducted universities, institutions, departments, aims, research methods, research designs, studied samples, used sampling methods, preferred sample sizes, used data collection tools, and data analysis techniques of postgraduate theses were examined.

The study was designed with document review method among the qualitative research methods. The theses within the scope of the study were determined with criterion sampling. Accordingly, 88 theses that are accessible and registered in the Council of Higher Education Thesis Center were examined. Thesis review form was used in the examination of the accessed theses. Content analysis was used in the analysis of the obtained data. The obtained data were coded to the thesis review form by the researcher according to the categories. Frequency (f) was used in the analysis of the data and the data was presented in graphics.

A great majority of the postgraduate theses on spatial ability consists of master's theses. Most of the theses were written in Turkish. Additionally, there is an increase in theses in recent years. There weren't any master's theses between 1997-2004 and doctoral theses between 1996-2009. The first doctoral thesis was conducted in 2010. Doctoral theses were mostly conducted under the advisory of professors and master's theses were mostly conducted under the advisory of doctor lecturers. Theses on spatial ability were conducted in 30 different universities. It was observed that Middle East Technical University, Marmara University, and Eskişehir Osmangazi University are the leading universities in which master's theses were conducted and Middle East Technical University, Marmara University, and Dokuz Eylül University are the leading universities in which doctoral theses were conducted. Additionally, master's and doctoral theses were mostly conducted in the institutions 
of educational sciences and science. A great majority of master's and doctoral theses were conducted in Elementary, Secondary School Mathematics and Science Education, Computer and Instructional Technology, departments. It was observed that in master's and doctoral theses on spatial ability, "effects on the spatial ability of the different applications" were intended the most. It was observed that in master's and doctoral theses on spatial ability, quantitative and mixed methods were used the most. It was revealed that experimental design was used intensely both in master's and doctoral theses. Both master's and doctoral theses conducted on spatial ability predominantly studied middle-school students. Simple random sampling method was used the most in the theses. There were also master's and doctoral theses that did not perform sampling. Additionally, most of the master's and doctoral theses did not specify the used sampling method. Moreover, the sample size of 1-50 and 51-100 people was preferred in the master's theses. It can be observed that various data collection tools and data analysis techniques were used in postgraduate theses conducted on spatial ability. Data collection tools such as tests, interviews, and scale were used predominantly both in master's and doctoral theses conducted on this field. It was observed that data analysis techniques used in most of the master's theses were respectively descriptive statistics, comparison tests, validity-reliability analyses, and assumption analyses; and descriptive statistics, validity-reliability analyses, comparison tests, and assumption analyses were respectively, the most used techniques in doctoral theses.

In conclusion, it was determined that the number of master's theses conducted on spatial ability were more than the doctoral theses, the highest number of master's theses were written in 2016 and 2018 and the highest number of doctoral theses were written in 2012, 2017 and 2019, the advisors of doctoral theses were mostly professors and the advisors of master's theses were mostly assistant professor, the highest number of these were conducted in Middle East Technical and Marmara University, and the institutions were Education and Science institutions, and the departments were Elementary, the most intended purpose were "effects on the spatial ability of the different applications", the most used research method was quantitative and mixed research, the most preferred research design was experimental design, the most studied group was middle-school students, simple random sampling method was used, sample size of 1-50 people was preferred, the most preferred data 
collection tool was tests, and the most preferred data analysis technique was descriptive statistics. As can be seen, there were similarities in postgraduate theses in terms of the examined variables. It can be suggested to use qualitative or mixed research methods in order to acquire more thorough information in future studies. It can be suggested to include different research designs and data collection tools that are preferred less instead of certain research designs and data collection tools. Additionally, it can be also suggested to diversify the analysis methods used for the analysis of the data and to use advanced statistical and analysis techniques.

\section{Kaynakça / References}

Abay, S., Tertemiz, N. ve Gökbulut, Y. (2018). Invastigation in several variables the spatial skills of teacher candidates. Necatibey Eğitim Fakültesi Elektronik Fen ve Matematik Eğitimi Dergisi, 12(1), 45-62.

Baki, A. ve Gökçek, T. (2012). Karma yöntem araştırmalarına genel bir bakış. Elektronik Sosyal Bilimler Dergisi, 11(42), 1-21.

Bennett, G. K., Seashore, H. G. ve Wesman, A. G. (1974). The differential aptitude tests (Form $t$ ). New York: The Psychological Corporation.

Bishop, A. J. (1980). Spatial abilities and mathematics education-A review. Educational studies in mathematics, 11(3), 257-269.

Cansız Aktaş, M. (2015). Nitel veri toplama araçları. M. Metin (Ed.), Kuramdan uygulamaya eğitimde bilimsel araştrrma yöntemleri içinde. (s. 337-371) Ankara: Pegem Akademi Yayincilk.

Cheng, Y. L. ve Mix, K. S. (2014). Spatial training improves children's mathematics ability. Journal of Cognition and Development, 15(1), 2-11.

Clements, D. H. (1998). Geometric and spatial thinking in young children. ERIC Document Reproduction Service No. ED 436232.

Coleman, S. L. ve Gotch, A. J. (1998). Spatial perception skills of chemistry students. Journal of Chemical Education, 75(2), 206.

Contero, M., Naya, F., Company, P., Saorin, J. L. ve Conesa, J. (2005). Improving visualization skills in engineering education. IEEE Computer Graphics and Applications, 25(5), 24-31.

Corradini, A. (2011). A study on whether digital games can effect spatial reasoning skills. Handbook of Research on Improving Learning and Motivation through Educational Games: Multidisciplinary Approaches. IGI Global, 1, (pp.1086-1110).

Çepni, S. (2014). Araştırma ve proje çalışmalarına giriş. (7. Baskı). Trabzon: Celepler Matbaacilik. 
Delialioğlu, Ö. ve Aşkar, P. (1999). Contribution of students'logical thinking ability, mathematical skills and spatial ability on achievement in secondary school physics. Hacettepe Üniversitesi Ĕ̈itim Fakültesi Dergisi, 16-17, 34-39.

Demetriou, A., Christou, C., Spanoudis, G. ve Platsidou, M. (2002). The development of mental processing: Efficiency, working memory, and thinking. Monographs of the Society of Research in Child Development (Serial Number 267).

Demirkaya, C. ve Masal, M. (2017). Geometrik-mekanik oyunlar temelli etkinliklerin ortaokul öğrencilerinin uzamsal düşünebilme becerilerine etkisi. Sakarya University Journal of Education, 7(3), 600-610.

Dokumacı Sütçü, N. (2017). Zekâ oyunlarmin ortaokul 7. sminf öğrencilerinin uzamsal yeteneklerine ve uzamsal yetenek öz-değerlendirmelerine etkisi. Yayınlanmamış doktora tezi. Dicle Üniversitesi, Diyarbakır.

Dokumacı Sütçü, N. (2018, Mayıs). Ortaokul öğrencilerinin uzamsal görselleştirme becerilerinin incelenmesi. Proceedings of the $V^{\text {th }}$ International Eurasian Educational Research Congress, Antalya. s. 197-199

Ekstrom, R. B., Dermen, D. ve Harman, H. H. (1976). Manual for kit of factor-referenced cognitive tests. Princeton, NJ: Educational Testing Service.

Eliot, J. ve Smith, I. M. (1983). An international directory of spatial tests. Windsor, UK, NFER-Nelson.

Erkek, Ö., Işıksal, M. ve Çakıroğlu, E. (2017). Öğretmen adaylarının uzamsal görselleştirme yetenekleri ve uzamsal kaygıları üzerine bir çalışma. Kastamonu Eğitim Dergisi, 25(1), 33-50.

Erkuş, A. (2009). Dauranış bilimleri için bilimsel araştırma süreci. Ankara: Seçkin Yayınclık.

Ferguson, A. M., Maloney, E. A., Fugelsang J. ve Risko, E. F. (2015). On the relation between math and spatial ability: The case of math anxiety. Learning and Individual Differences, 39, 1-12.

Göktepe Yıldız, S. ve Özdemir, A. S. (2017). Development of the spatial ability test for middle school students. Acta Didactica Napocensia, 10(4), 41-54.

Guay, R. B. (1976). Purdue spatial visualization test. West Lafayette, Indiana: Purdue Research Foundation.

Gürbüz, R., Erdem, E. ve Güllburnu, M. (2018). Sekizinci sınıf öğrencilerinin matematiksel muhakemeleri ile uzamsal yetenekleri arasındaki ilişki. Kastamonu Ĕ̆itim Dergisi, 26(1), 1-6.

Gürdal, A., Bakioğlu, A. ve Öztuna, A. (2010). Fen bilgisi eğitimi lisansüstü tezlerinin incelenmesi. Dokuz Eylül Üniversitesi Buca Eğitim Fakültesi Dergisi, 17. 
Güven, B. ve Kösa, T. (2008). The effect of dynamic geometry software on student mathematics teachers' spatial visualization skills. Turkish Online Journal of Educational Technology-TOJET, 7(4), 100-107.

Hartman, N. W. ve Bertoline, G. R. (2005, July). Spatial abilities and virtual technologies: Examining the computer graphics learning environment. Information Visualisation, Proceedings. Ninth International Conference on (p. 992-997). IEEE.

Hauptman, H. (2010). Enhancement of spatial thinking with Virtual Spaces 1.0. Computer \& Education, 54, 125-135.

İrioğlu, Z. ve Ertekin, E. (2012). İlköğretim ikinci kademe öğrencilerinin zihinsel döndürme becerilerinin bazı değiş̧kenler açısından incelenmesi. Journal of Educational and Instructional Studies in the World, 2(1), 75-81.

Juodaitytė, A. ve Kazlauskienè, A. (2008). Research methods applied in doctoral dissertations in education science (1995-2005): Theoretical and empirical analysis. Vocational Education: Research \& Reality, 15, 36-45.

Karasar, N. (2011). Bilimsel araştırma yöntemi (22. Baskı). Ankara: Nobel Yayın Dağıtım.

Kospentaris, G. ve Spyrou, P. (2010). The effects of high school geometry instruction on the performance in spatial tasks. Journal for Geometry and Graphics, 14(2), 227244.

Lin, C. H. ve Chen, C. M. (2016). Developing spatial visualization and mental rotation with a digital puzzle game at primary school level. Computers in Human Behavior, 57, 23-30.

Liner, M. S. (2012). Spatial ability and achievement in high school physics. Unpublished doctoral dissertation. Louisiana State University.

Linn, M. C. ve Petersen, A. C. (1985). Emergence and characterization of gender differences in spatial abilities: A meta-analysis. Child Development, 56, 1479-1498.

Lohman, D. F. (1979). Spatial ability: A review and reanalysis of the correlational literature. (Tecnical Report No.8). Aptitude Research Project, School of Education, Stanford University.

Lohman, D. F. (1993, July). Spatial ability and g. Paper presented at the First Spearman Seminar, University of Plymouth.

Lowrie, T., Logan, T. ve Ramful, A. (2017). Visuospatial training improves elementary students'mathematics performance. British Journal of Educational Psychology, 87, 170-186.

Lubinski, D. (2010). Spatial ability and STEM: A sleeping giant for talent identification and development. Personality and Individual Differences, 49(4), 344-351. 
Martin-Dorta, N., Sanchez-Berriel, I., Bravo, M., Hernandez, J., Saorin, J. L. ve Contero, M. (2014). Virtual blocks: A serious game for spatial ability improvement on mobile devices. Multimedia Tools and Applications, 73(3), 1575-1595.

Mathewson, J. H. (1999). Visual-spatial thinking: An aspect of science overlooked by educators. Science Education, 83(1), 33-54.

McGee, M. G. (1979). Human spatial abilities: Psychometric studies and environmental, genetic, hormonal, and neurological influences. Psychological Bulletin, 86(5), 889.

Miles, M. B. ve Huberman, A. M. (1994). Qualitative data analysis: An expanded sourcebook. Thousand Oaks, CA: Sage.

Mohler, J. L. (2006). Examining the spatial ability phenomenon from the student's perspective Unpublished doctoral dissertation. Purdue University, West Lafayette, Indiana.

Newcombe, N. S. ve Shipley, T. F. (2015). Thinking about spatial thinking: New typology, new assessments. In studying visual and spatial reasoning for design creativity (p.179-192). Springer Netherlands.

Newman, S. D., Hansen, M. T. ve Gutierrez, A. (2016). An fMRI study of the impact of block building and board games on spatial ability. Frontiers in Psychology, 7, 1278.

Olkun, S. (2003a). Making connections: Improving spatial abilities with engineering drawing activities. International Journal of Mathematics Teaching and Learning, 3(1), 1-10.

Olkun, S. (2003b). Comparing computer versus concrete manipulatives in learning 2D geometry. Journal of Computers in Mathematics and Science Teaching, 22(1), 43-46.

Osberg, K. M. (1997). Spatial cognition in the virtual environment. Technical Report-97 18. Seattle: Human Interface Technology Laboratory, University of Washington.

Özkan, U. B. (2019). Ĕ̈itim bilimleri araştırmalan için doküman inceleme yöntemi. Ankara: Pegem Akademi.

Pallrand, G.J. ve F. Seeber (1984). Spatial ability and achievement in introductory physics. Journal of Research in Science Teaching, 21(5), 507-16.

Pellegrino, J. W., Alderton, D. L. ve Shute, V. J. (1984). Understanding spatial ability. Educational Psychologist, 19(4), 239-253.

Peters, M., Chisholm, P. ve Laeng, B. (1995). Spatial ability, student gender, and academic performance. Journal of Engineering Education, 84(1), 69-73.

Pittalis, M. ve Christou, C. (2010). Types of reasoning in 3D geometry thinking and their relation with spatial ability. Educational Studies in Mathematics, 75(2), 191-212. 
Pribyl, J. R. ve Bodner, G. M. (1987). Spatial ability and its role in organic chemistry: A study of four organic courses. Journal of Research in Science Teaching, 24(3), 229240.

Russell-Gebbett, J. (1985). Skills and strategies-pupils'approaches to three-dimensional problems in biology. Journal of Biological Education, 19, $293-297$.

Sarı, M. H. (2016). Uzamsal beceri ve uzamsal kaygı arasındaki ilişki: Sını öğretmeni adayları üzerine bir araştırma. Turkish Journal of Computer and Mathematics Education, 7(3), 646.

Senemoğlu, N. (2012). Gelişim, öğrenme veöğretim, kuramdan uygulamaya. Ankara: Pegem Akademi.

Shepard, R. N. ve Metzler, J. (1971). Mental rotation of three-dimensional objects. Science, 171(3972),701-703.

Sjölinder, M. (1998). Spatial cognition and environmental descriptions. N. Dahlbäck (Ed.), In exploring navigation: Towards a framework for design and evaluation of navigation in electronic spaces (p. 46-58).

Sönmez, V. ve Alacapınar, F. G. (2016). Örneklendirilmiş bilimsel araştrma yöntemleri. Ankara: Anı Yayıncilik.

Şimşek, E. ve Koru Yücekaya, G. (2014). Dinamik geometri yazılımı ile öğretimin ilköğretim 6. sinuf öğrencilerinin uzamsal yeteneklerine etkisi. Ahi Evran Üniversitesi Kırşehir Ĕ̈itim Fakültesi Dergisi, 15(1), 65-80.

Tartre, L. A. (1990). Spatial orientation skill and mathematical problem solving. Journal for Research in Mathematics Education, 21, 216-229.

Tracy, D. M. (1990). Toy playing behaviour, sex role orientation, spatial ability and science achievement. Journal for Research in Science Teaching, 27, 637-649.

Turgut, M., Yenilmez, K. ve Balbağ, M. Z. (2017). Öğretmen adaylarının mantiksal ve uzamsal düşünme becerileri: Bölüm, cinsiyet ve akademik performansin etkisi. Mehmet Akif Ersoy Üniversitesi Eğitim Fakültesi Dergisi, 1(41), 265-283.

Turgut, M. (2015). Development of the spatial ability self-report scale (SASRS): Reliability and validity studies. Quality \& Quantity, 49(5), 1997-2014.

Turgut, M. ve Yenilmez, K. (2012). Matematik öğretmeni adaylarının uzamsal görselleştirme becerileri. Eğitim ve Öğretim Araştırmalan Dergisi, 1(2), 243-252.

Turgut, M. ve Yllmaz, S. (2012). İlköğretim 7. ve 8. sinff öğrencilerinin uzamsal yeteneklerinin incelenmesi. Dicle Üniversitesi Ziya Gökalp Eğitim Fakültesi Dergisi, 19, 69-79.

Uttal, D. H. ve Cohen, C. A. (2012). Spatial thinking and STEM education: When, why and how. Psychology of Learning and Motivation, 57(2), 147-181. 
Üzümcü,Ö. (2016). Nitel araştırma yöntemine sahip tezlerin bazı değişkenler açısından incelenmesi. Akademik Sosyal Araştrmalar Dergisi, 4(32), 327-340.

Winter, J. W., Lappan, G., Fitzgerald, W. ve Shroyer, J. (1989). Middle grades mathematics project: Spatial visualization. NY: Addison-Wesley.

Yazar, T. ve Dokumac Sütçü, N. (2018). Öğretmen yetiştirmede araştırma yönelimleri: 2000'li yllarda (2000-2018) öğretmen yetiştirme ile ilgili yapulan lisansüstü tezlerin incelenmesi. M. Ergün, B. Oral ve T. Yazar (Ed.), Öğretmen yetiştirme sistemimiz: dün, bugün ve yarı, içinde (s.563-599). Ankara: Pegem Akademi Yayıncillk.

Yıldırım, A. ve Şimşek, H. (2011). Sosyal bilimlerde nitel araştırma yöntemleri. Ankara: Seçkin Yayıncllık.

Yıldız, B. ve Tüzün, H. (2011). Üç-boyutlu sanal ortam ve somut materyal kullanımının uzamsal yeteneğe etkileri. Hacettepe Üniversitesi Eğitim Fakültesi Dergisi, 41(41).

Yılmaz, K. ve Altnkurt, Y. (2012). An examination of articles published on preschool education in Turkey. Educational Sciences: Theory and Practice. Special Issue, 3227-3241.

Young, C. J., Cartmill, E. A., Levine, S. C. ve Goldin-Meadow, S. (2014, July). Gesture and speech input are interlocking pieces: The development of children's jigsaw puzzle assembly ability. P. Bello, M. Guarini, M. McShane, ve B. Scassellati (Eds.), Proceedings of the 36th Annual Meeting of the Cognitive Science Society (p. 1820-1825).

Yurt, E. veSünbül, A. M. (2012). Sanal ortam ve somut nesneler kullanılarak gerçekleştirilen modellemeye dayalı etkinliklerin uzamsal düşünme ve zihinsel çevirme becerilerine etkisi. Kuram ve Uygulamada Ĕ̆itim Bilimleri. 12(3), 1975-1992.

\section{Kaynakça Bilgisi / Citation Information}

Dokumacı Sütçü, N. (2021). Türkiye' de uzamsal yeteneğe ilişkin araştırma eğilimleri. OPUS-Uluslararası Toplum Araştırmaları Dergisi, 17(36), 2605-2636. DOI: 10.26466/opus.839496 